\title{
New Paleomagnetic Data From Thurston Island: Implications for the Tectonics of West Antarctica and Weddell Sea Opening
}

\author{
A. M. GRuNow ${ }^{1}$ \\ Byrd Polar Research Center, Ohio State University, Columbus \\ D. V. KENT \\ Lamont-Doherty Geological Observatory and the Department of Geological Sciences, Columbia University, New York
}

\author{
I. W. D. DalzIEL \\ Institute for Geophysics, University of Texas at Austin
}

\begin{abstract}
Paleomagnetic data from three West Antarctic crustal blocks (Antarctic Peninsula (AP), Thurston Island-Eights Coast (TI), and the Ellsworth-Whitmore Mountains (EWM) indicate that there has been motion between the individual blocks and motion relative to East Antarctica during the Mesozoic. A Triassic paleomagnetic pole from the TI block $\left(116^{\circ} \mathrm{E}, 61^{\circ} \mathrm{S}, A_{05}=19.4^{\circ}, N=3 \mathrm{VGPs}\right)$ appears to indicate that the block has rotated $\sim 90^{\circ}$ relative to East Antarctica between $230 \mathrm{Ma}$ and $110 \mathrm{Ma}$. Our previously reported Middle Jurassic paleomagnetic pole from the EWM block indicates that a $90^{\circ}$ rotation relative to East Antarctica occurred sometime between the Cambrian and $175 \mathrm{Ma}$. We believe that the $90^{\circ}$ counterclockwise EWM rotation occurred between $\sim 220 \mathrm{Ma}$ and $175 \mathrm{Ma}$ related to the development of post-Gondwanide Orogeny shear zones. The motion of the AP, TI, and EWM blocks appears to be linked during the mid- to late Mesozoic to three major events in the evolution of the southem ocean basins. Opening in the Mozarnbique-Somali-Weddell Sea basins may have produced major counterclockwise rotation of the TI block with respect to East Antarctica between the Jurassic and Early Cretaceous based on new Late Jurassic $\left(145^{\circ} \mathrm{E}, 64.5^{\circ} \mathrm{S}, A_{95}=7^{\circ}, N=5 \mathrm{VGPs}\right)$ poles. We believe that the TI rotation, as well as deformation in the southem AP block, was caused by collision and shearing of the EWM block against the other two as the EWM block moved southward with East Antarctica. An Early Cretaceous paleomagnetic pole $\left(232^{\circ} \mathrm{E}, 49^{\circ} \mathrm{S}, A_{95}=7.9^{\circ}, N=5\right.$ VGPs) from the TI block requires that between the Early and mid-Cretaceous there was clockwise rotation, with respect to East Antarctica, of the AP-TI-EWM blocks (an entity we call Weddellia). A change in the opening history of the Weddell Sea basin caused by initiation of spreading in the South Atlantic ocean basin at -130 Ma probably started Weddellia's clockwise rotation. Two new $\sim 110$ and $-90 \mathrm{Ma}$ poles from the TI block $\left(210^{\circ} \mathrm{E}, 73^{\circ} \mathrm{S}, A_{95}=7.6^{\circ}, N=7\right.$ VGPs and $161^{\circ} \mathrm{E}, 81^{\circ} \mathrm{S}, A_{95}=3.9^{\circ}, N=18 \mathrm{VGPs}$, respectively) are similar toequivalent age poles from the $\mathrm{AP}$ block and East Antarctica and indicate that Weddellia was at ornear its present-day position with respect to East Antarctica by $\sim 10 \mathrm{Ma}$. This corresponds to a time of major plate reorganization in the South Atlantic and southeast Indian Oceans. Based on both the new TI paleomagnelic data and previously reported data from Marie Byrd Land (MBL), dextral shearing would be expected to have occurred between MBL and Weddellia since the mid-Cretaceous. Pine Island Bay, the area between the TI and MBL, blocks, marks a fundamental and complex tectonic boundary in West Antarctica that we propose has largely been a zone of transcurrent shearing.
\end{abstract}

\section{INTRODUCTION}

The position of West Antarctica with respect to cratonic East Antarctica prior to and after breakup of Gondwanaland is critical to the opening history of the Weddell Sea. West Antarctica, however, is not a single tectonic entity but rather is composed of four major crustal blocks whose relation to each other and to East Antarctica is not well understood. These crustal blocks or terranes are the Antarctic Peninsula (AP), the Ellsworth-Whitmore Mountains (EWM), the Thurston IslandEights Coast (TI), and Marie Byrd Land (MBL) [Jankowski and Drewry, 1981; Dalziel and Elliot, 1982] (Figure 1). The focus of this paper is on new paleomagnetic data from the TI block combined with existing paleomagnetic, geologic, and geophysical data from Gondwanaland that links the movement of the West Antarctic crustal blocks to the Mesozoic evolution of the southern ocean basins.

\footnotetext{
1Now at Department of Earth Sciences, University of Oxford, Oxford, England.

Copyright 1991 by the American Geophysical Union.

Paper number $91 \mathrm{JB} 01507$

0148-0227/91/91JB-01507\$05.00
}

\section{GEOLOGIC OVERVIEW OF WEST ANTARCTICA}

The AP and TI blocks are composed primarily of Mesozoic and Cenozoic arc intrusive and extrusive rocks associated with the Pacific convergent margin of Gondwanaland [Smellie, 1981; Thomson and Pankhurst, 1983; Pankhurst, 1990]. Early Paleozoic basement representing the roots of a magmatic arc indicate that parts of the AP block have been along a convergent margin since the Paleozoic [Pankhurst, 1982, 1983; Harrison and Loske, 1988; Milne and Millar, 1991]. The EWM block consists primarily of a Precambrian basement at Haag Nunataks [Millar and Pankhurst, 1987] and a Paleozoic sedimentary succession in the Ellsworth Mountains [Webers and Sporli, 1983] that has often been correlated with the stratigraphic succession in the Pensacola Mountains, East Antarctica (Figure 1) [Schopf, 1969; Dalziel and Elliot, 1982]. MBL consists of Paleozoic sedimentary and igneous rocks that were intruded by mid-Cretaceous granitoids; it is most closely associated with the Paleozoic rocks of North Victoria Land (East Antarctica) and with New Zealand [Bradshaw et al., 1983].

Various positions have been suggested for the West Antarctic crustal blocks in a pre breakup Gondwanaland reconstruction [Schopf, 1969; Smith and Hallam, 1970; De Wit, 1977; Barron 
et al., 1978; Norton and Sclater, 1979; Dalziel and Elliot, 1982; Powell et al., 1982; LaBrecque, 1985; Elliot, 1991]. Norton and Sclater [1979] showed that the du Toit [1937] and Smith and Hallam [1970] fit of the major continental fragments of Gondwanaland was essentially correct but that an unacceptable overlap of the AP block with the Falkland Plateau occurs if West Antarctica is left in its present-day position with respect to East Antarctica. Together with the geographic isolation and anomalous structural trend of the Ellsworth Mountains fold belt, this overlap constituted the primary reason to consider relative motion among the crustal blocks of West Antarctica [Schopf, 1969; Dalziel and Elliot, 1982]. Paleomagnetic data support a $90^{\circ}$ counterclockwise rotation of the EWM block from the Transantarctic margin of East Antarctica (probably near Coats Land; Figure 1) since the Late Cambrian [Watts and Bramall, 1981; Grunow et al., 1987a].

Paleomagnetic data obtained from Middle Jurassic rocks in the EWM block yielded a paleomagnetic pole very similar to a Middle Jurassic pole from the AP block [Longshaw and Griffiths, 1983; Grunow et al., 1987a]. An Early Cretaceous TI pole [Grunow et al., 1987b] was indistinguishable from the Middle Jurassic AP and EWM poles and was interpreted by us as possibly indicating little apparent polar wander for these blocks between the Middle Jurassic and Early Cretaceous [Grunow et al., 1987b]. This led us to suggest that the AP-
EWM-TI blocks may have acted a tectonic entity which we refer to as Weddellia, between the Middle Jurassic and Cretaceous, insofar as can be resolved paleomagnetically [Grunow et al., 1987b]. If the AP, EWM, and TI blocks are joined in their present-day relative positions (rigid Weddellia), there is an overlap of the AP block with southem South America. Geosat, marine, and airborne gravity data [Sandwell and McAdoo, 1988; Bell et al., 1990] indicate that the continental margin of the Antarctic Peninsula is much narrower than necessarily inferred by the imprecise location of the shelf-slope break in ice-covered waters, and this lessens the pre-breakup overlap shown for the AP block with southern South America [Grunow et al., 1987b]. A reconstruction with the blocks separated (mosaic Weddellia) fits the geologic and paleomagnetic data better but requires a more complex opening history for the Weddell Sea basin [Grunow et al., 1987b; Lawver and Scotese, 1987; Lawver et al., 1991].

\section{GEOLOGIC SETTING OF TI BLOCK}

The TI block consists of the area known as Thurston Island and the Eights Coast between $255^{\circ} \mathrm{E}$ (Pine Island Bay) and $\sim 270^{\circ} \mathrm{E}$ and from $71^{\circ} \mathrm{S}$ to $\sim 75^{\circ} \mathrm{S}$. Thurston Island is separated from the Eights Coast by the Abbot Ice Shelf, which is found within a graben or half graben structure (Figure 1). The rocks

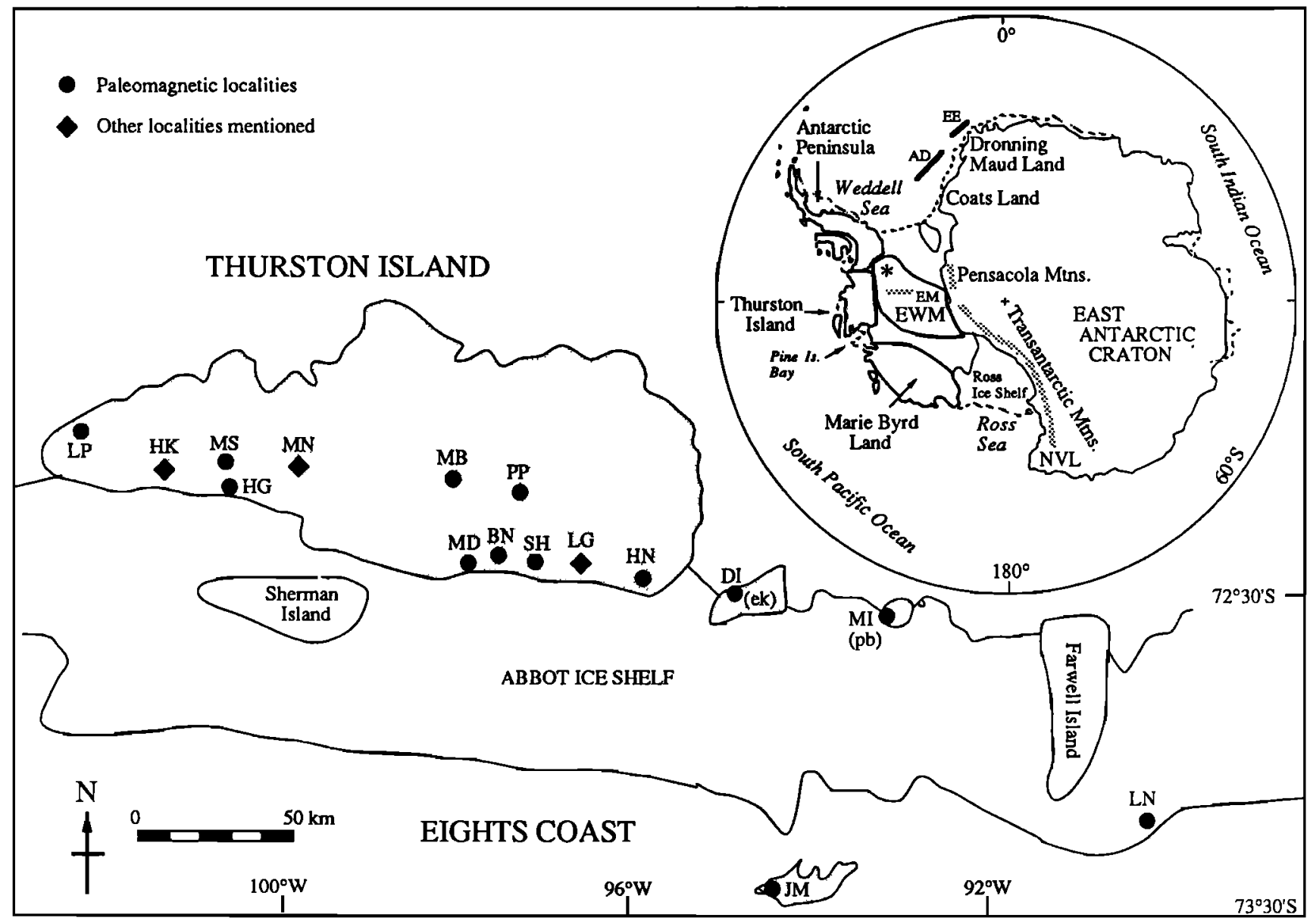

Fig. 1. Sample locations on Thurston Island: BN, Belknap Nunatak; DI, Dustin Island (ek, Ehlers Knob); HG, Hale Glacier; HN, Harrison Nunatak; JM, Jones Mountains; LN, Lepley Nunatak; LP, Landfall Peak; MB, Mounta Bramhall; MB, Mount Dowling; MI, McNamara Island (pb, Pellers Bluff); MS, Mount Simpson; PP, Parker Peak; SH, Shelton Head. Other locations: HK, Henderson Knob; MN, Mount Noxom. Inset shows the West Antarctic crustal blocks (boldly outlined) in their present-day positions with respect to East Antarctica. EWM, Ellsworth-Whitmore Mountains; EM, Ellsworth Mountains; NVL, North Victoria Land; asterisk, Haag Nunataks. Stippled lines show mountain trends; slanted lines show location of ice shelves. 
on Thurston Island crop out along two general east-west striking zones, parallel to the Abbot Ice Shelf. The majority of rock exposures from the TI block are of intrusive rocks with minor outcrops of volcanic rocks that are thought to represent evolution along a convergent margin during the Mesozoic. A more complete description of the rocks is given by Craddock et al. [1964a, 1969], Lopatin and Orlenko [1972], Wade and Wilbanks [1972], and Storey et al. [1991]. The oldest rocks known from TI are Carboniferous gneisses thought to represent the roots of a magmatic arc [Craddock et al., 1964b; Pankhurst, $1990]$. Triassic granodiorites ( $230 \mathrm{Ma})$ at Mount Bramhall [Grunow et al., 1990] and Lower Jurassic granites ( $200 \mathrm{Ma})$ in the Jones Mountains [Craddock et al., 1969; Pankhurst, 1990] indicate magmatic activity on Thurston Island in the early Mesozoic. A series of $\sim 140$ to $155 \mathrm{Ma}$ granites, granodiorites and diorites represent another phase of magmatic activity on Thurston Island [Storey et al., in press]. Mid- to Late Cretaceous volcanism and felsic dike intrusion occurred in the Jones Mountains [Craddock et al., 1963a], while granitic magmas were being emplaced at Lepley Nunatak [Grunow et al., 1990]. These magmatic rocks indicate that TI was along a convergent margin until the latest Cretaceous-earliest Tertiary when subduction probably ceased as a result of eastward propogation of the Pacific-Antarctic ridge [Watts et al., 1988].
The Mesozoic rocks in the Jones Mountains are unconformably overlain by glacial till and flat-lying Tertiary alkaline volcanics [Craddock et al., 1969; Rutford et al., 1972]. The thermal event that produced the Tertiary alkalic basalts may have also created the grabenlike structure in which the Abbot Ice Shelf is found (Figure 1).

\section{SAMPLING AND LaBoratory PROCEDURES}

The paleomagnetic samples (along with geochronologic, geochemical, and structural studies collected by other members of the project) were collected as part of the joint U.S.-U.K. West Antarctic tectonics project [see Dalziel and Pankhurst, 1987] in the hope of better constraining the relative motion of the West Antarctic blocks and the opening history of the Weddell Sea. Paleomagnetic samples in the TI block were collected by A.M. Grunow using a portable, gasoline-powered, diamond-bit coring drill with glycol as a drill coolant. Over 700 oriented drill samples and 10 oriented hand samples were collected from 123 sites at 28 locations in the TI block. Generally six to seven cores were sampled at each site and oriented using a Brunton compass. Sun compass measurements were made at each locality to allow correction for local magnetic variation. The Sun compass measurements from the intrusive and volcanic localities (Table 1) were always within
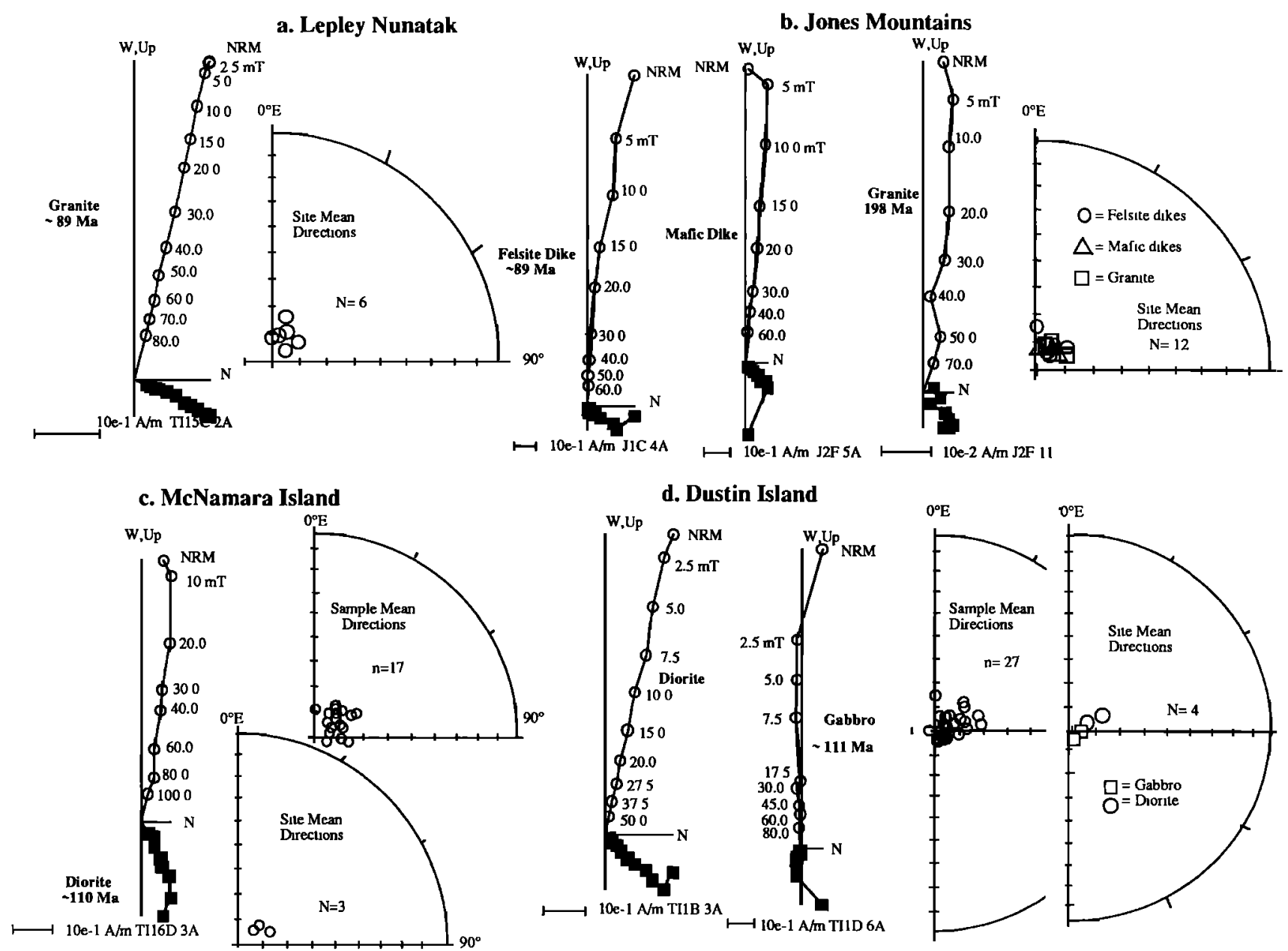

Fig. 2. Orthogonal projection of vector endpoint diagrams showing demagnetization behavior of samples from Thurston Island. Open circles (solid circles) are projections on the vertical (horizontal) planes at indicated levels of AF (mT, millitesla) or TH $\left({ }^{\circ} \mathrm{C}\right.$ ) cleaning. Equal-angle projections of characteristic cleaned sample and site mean directions. Open (solid) symbols are on the upper (lower) hemisphere. Intensity plots are shown for localities where TH demagnetization was used to determine the directions. 
e. Harrison Nunatak

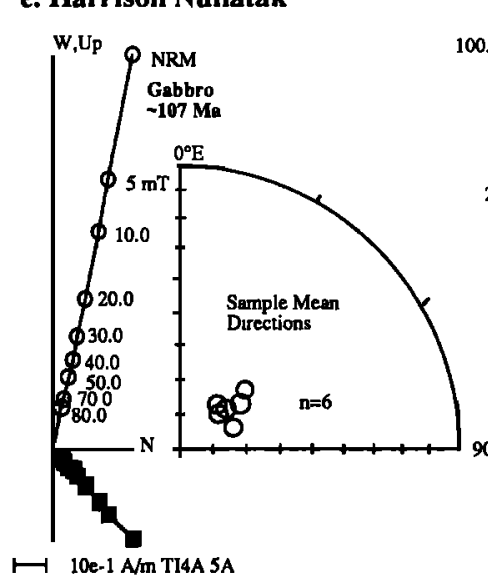

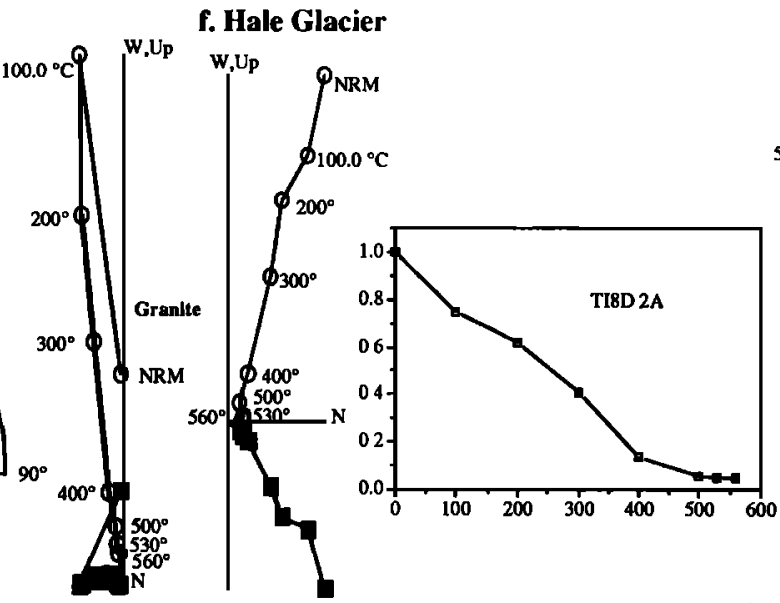

$\longmapsto$ 10e-2 A/m TI8D 7B $\longmapsto 10 \mathrm{e}-2 \mathrm{~A} / \mathrm{m}$ TI8D 2A g. Parker Peak

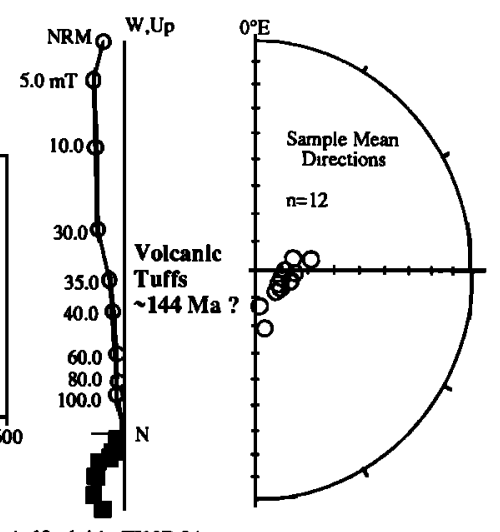

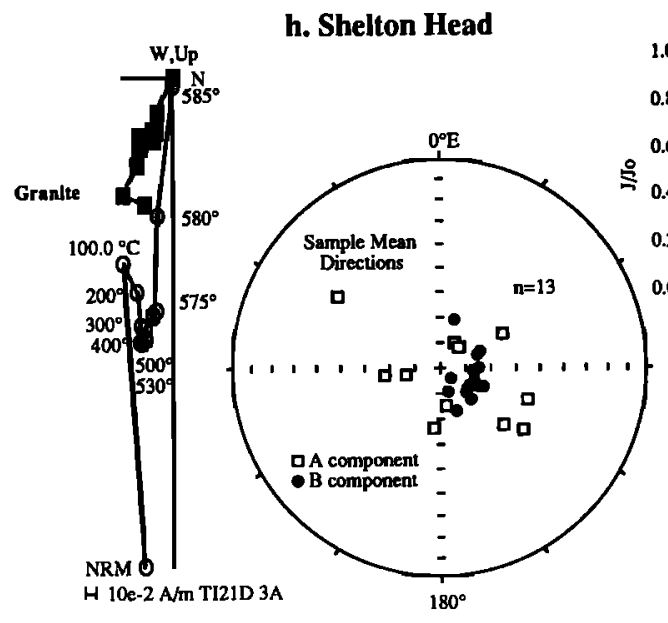

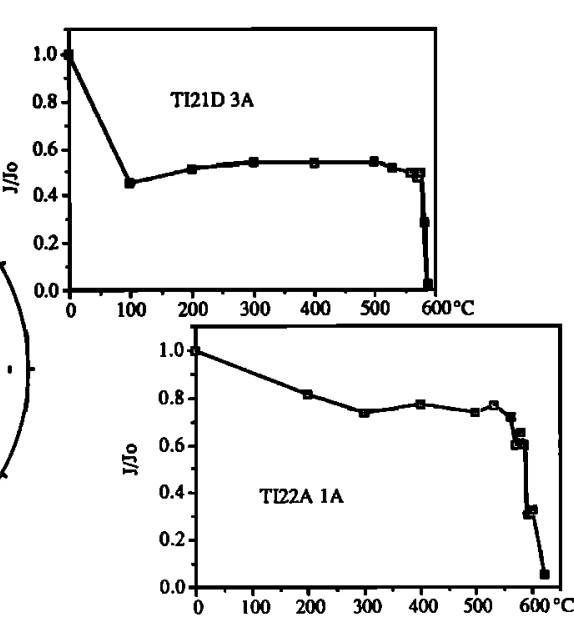

$\mapsto$ 10e-1 A/m TI10B 2A

\section{i. Mt. Simpson}

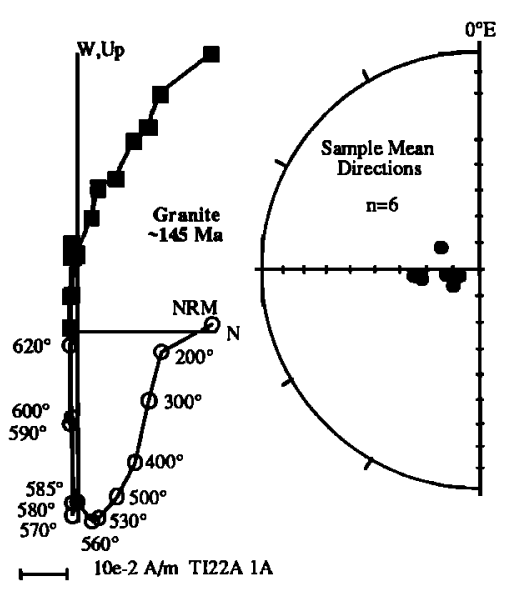

j. Landfall Peak
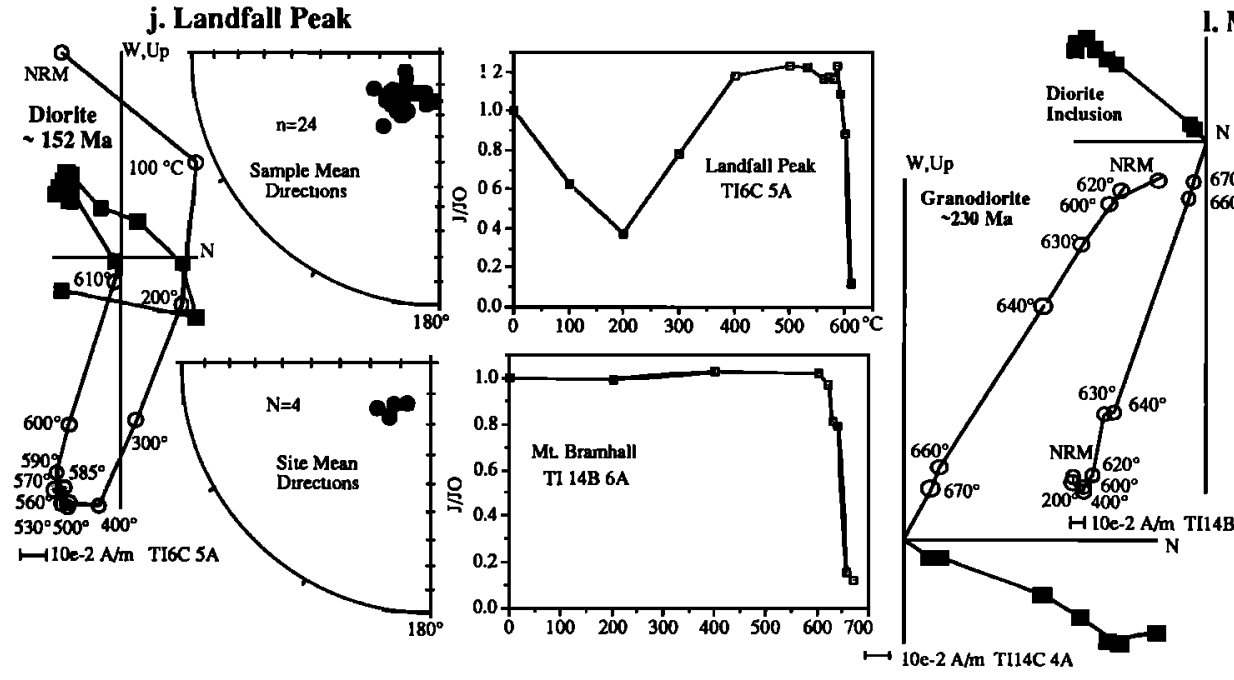

1. Mt. Bramhall

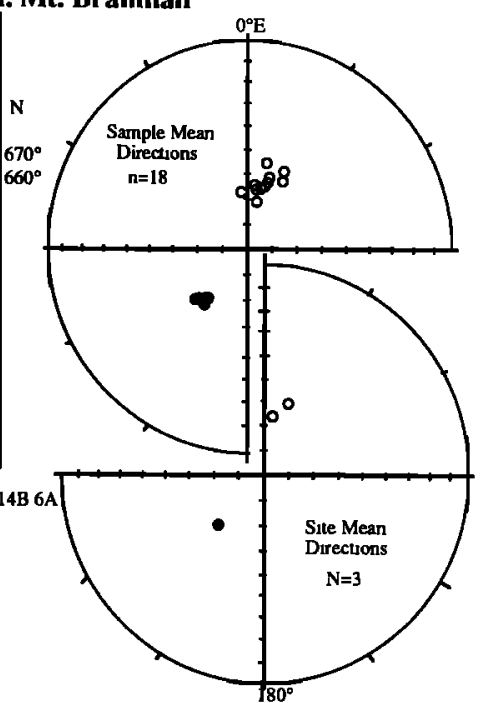

Fig. 2. (continued)

$3^{\circ}$ of the predicted magnetic variation and therefore no corrections were made. Because most of the rocks exposed in the TI block are intrusions, we attempted to sample over as many widely scattered sites and different cooling units as possible within any given intrusion in order to average out secular variation and assess the likelihood of tectonic tilting. We were sometimes unable to collect more than one or two sites at a given location due to weather conditions.
The samples were analyzed in the paleomagnetic laboratory at Lamont-Doherty Geological Observatory. Measurements of the natural remanent magnetization (NRM) were made using a cryogenic magnetometer or a computerized flux gate spinner magnetometer on one or more specimens cut from each core. Pilot samples were progressively demagnetized using stepwise alternating field (AF) or thermal techniques (TH) to determine the best demagnetization procedure for that site. Steps of 


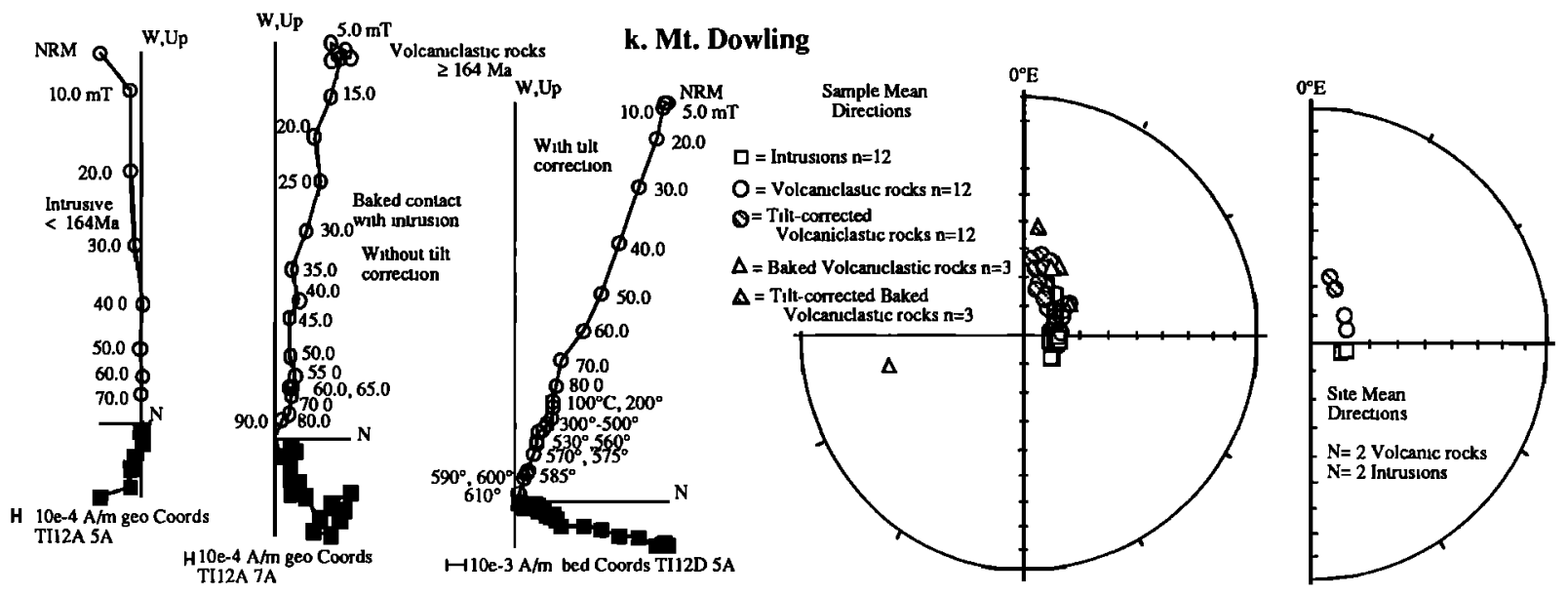

Fig. 2. (continued)

generally $10 \mathrm{mT}$ up to a peak of $100 \mathrm{mT}$ were used during AF demagnetization, while steps of $100^{\circ} \mathrm{C}$ up to $500^{\circ} \mathrm{C}$ beyond which smaller steps up to a maximum of $660^{\circ} \mathrm{C}$ were used in thermal demagnetization. The demagnetization data were plotted on vector endpoint diagrams and characteristic magnetization directions were calculated for linear segments converging toward the origin using principal component analysis [Kirschvink, 1980]. Directions were considered stable if defined by three or more colinear points. Mean directions for each locality are based on combining (specimen) sample means to site means and then site means to a unit mean using standard Fisher [1953] statistics. Location mean poles were calculated by using site-mean virual geomagnetic poles (VGPs).

\section{Paleomagnetic Results}

New paleomagnetic data are presented here for the TI block starting with the results from the youngest radiometrically dated rocks (see Figure 1 for locations). Radiometric age control is based on $\mathrm{Rb}-\mathrm{Sr}$ and $\mathrm{K}-\mathrm{Ar}$ analyses by R.J. Pankhurst and I.L. Millar of the British Antarctic Survey and the ${ }^{40} \mathrm{Ar} / 39 \mathrm{Ar}$ step-heating dating method by A.M. Grunow with T.M. Harrison and M.T. Heizler. The paleomagnetic results from the diorite/gabbro complex ( 124 Ma) at Belknap Nunatak have already been published [Grunow et al., 1987b].

\section{Lepley Nunatak}

A biotite-bearing granite $\left({ }^{40} \mathrm{Ar} /{ }^{39} \mathrm{Ar}\right.$ biotite isochron age of $89 \pm 1 \mathrm{Ma})$ cut by northeast trending mafic and feldpathic dikes forms low rounded hills at this isolated nunatak. A total of $\mathbf{4 0}$ cores from seven sites were drilled. A single component of magnetization pointing steeply upward to the north-northeast was consistently found in six of the granite and dike sites (Table 1 and Figure $2 a$ ). The seventh site (a mafic dike) yielded directions up and to the northwest and was excluded from further analysis. The unit mean direction for the six sites is $D=22.4^{\circ}$; $\mathrm{I}=-79.2^{\circ}$ (Table 2 and Figure $2 a$ ).

\section{Jones Mountains}

Two hundred and forty-five samples were drilled in the Jones Mountains from 34 sites in pink, coarse-grained granite (198 $\pm 2 \mathrm{Ma}$ ), volcanic rocks, mafic dikes, and pink and green felsic dikes $(89 \pm 3 \mathrm{Ma})$. The granite is cut by two generations of mafic dikes which in tum are cut by east-northeast trending felsic dikes. The Upper Cretaceous volcanic rocks are in fault contact with the granite and felsic dikes. The Mesozoic igneous rocks are overlain unconformably by Oligocene alkalineolivine basalts [Craddock et al., 1969; Rutford et al., 1972]. Results were obtained from $\sim 1 / 3$ of the sites by using AF demagnetization on three granite, six felsic dike, and three mafic dike sites. Pilot samples using thermal demagnetization produced results similar to the AF demagnetization.

A baked contact test carried out on the Lower Jurassic granite intruded by a mafic dike showed the granite yielding the same directions as the mafic dike (Figure $2 b$ ). Although no age determinations have been made on the mafic dikes, they yield directions very similar to the $89 \mathrm{Ma}$ felsic dikes (Table 1 and Figure $2 b$ ). The unit mean direction for the three granite sites is similar to the directions obtained by Scharnberger and Sharon [1972] from the granite. The site mean directions from both the granite and mafic dike sites are indistinguishable from the felsic dikes (Table 1 and Figure $2 b$ ). Therefore we believe that the granite has been remagnetized by the thermal event that produced the mid- to Upper Cretaceous volcanics and felsic dikes.

We assign an age of $-90 \mathrm{Ma}$ for the age of magnetization of the mafic and felsic dike sites and the overprinted granite. The mean direction for all 12 sites is $D=31.6^{\circ}, I=-80.1^{\circ}$ (Table 2).

\section{McNamara Island}

A medium- to coarse-grained, homblende + biotite-bearing diorite body at Peeler's Bluff on McNamara Island is cut by aplitic dikes and granitic sheets. The diorite locally contains what appeared to be a magmatic foliation (site TI16A, Table 1). Dating of the rocks at McNamara Island has proved difficult. Radiometric ages range between $97 \mathrm{Ma}$ (K-Ar biotite) [Drake et al., 1964] to $123 \mathrm{Ma}\left(\mathrm{Rb}-\mathrm{Sr}_{\mathrm{r}}\right.$ whole rock on the granite sheets) (R.J. Pankhurst, personal communication, 1990). We consider a $109 \mathrm{Ma} \mathrm{K}-\mathrm{Ar}$ hornblende age to approximate the age of magnetization because it was obtained from the paleomagnetic samples whereas the other radiometric ages are based on samples collected elsewhere at Peeler's Bluff. Also, petrographically, the paleomagnetic samples show significant secondary chloritization and alteration which may have locally caused remagnetization and radiometric resetting.

Four sites ( 23 cores) were drilled, three of the sites within the diorite and one within an aplitic dike. The aplitic dike proved 
TABLE 1. Site Mean Directions and Virtual Geomagnetic Poles From Thurston Island-Eights Coast

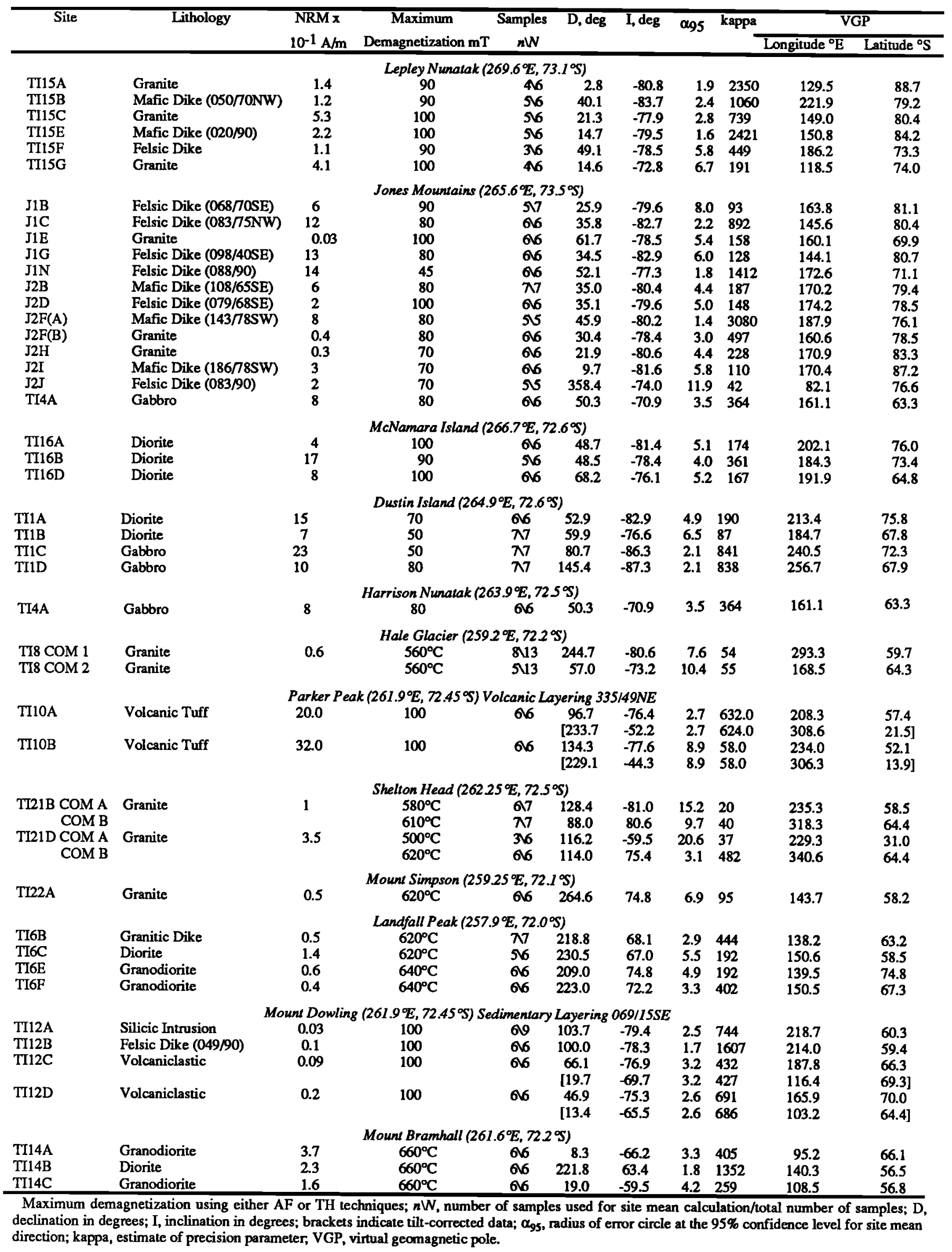


to be magnetically unstable. A single component of magnetization, defined by an upward pointing, northeast directed vector was found (Table 1 and Figure $2 c$ ). The unit mean direction for the three sites is $D=56.5^{\circ}, I=-78.8^{\circ}$ (Table 2 and Figure $2 c$ ).

\section{Dustin Island}

Two small exposures separated by $\sim 30 \mathrm{~m}$ of ice were visited at Ehlers Knob on Dustin Island (Figure 1). One was a coarsegrained diorite and the other a coarse-grained gabbro, the contact between which was not exposed. $\mathrm{K}-\mathrm{Ar}$ and $\mathrm{Rb}-\mathrm{Sr}$ biotite ages of $\sim 110 \mathrm{Ma}$ were obtained from the gabbro. Four sites ( 26 cores) were drilled, two sites in the gabbro, two sites in the diorite.

A single component of magnetization was observed in the diorite after AF demagnetization that was upward directed to the northeast (Table 1 and Figure 2d). These results are very similar to ones obtained by Scharnberger and Sharon [1972] from three sites in the diorite. A single, very steep component of magnetization was observed in the gabbro that was upward pointing to the east-southeast (Table 1 and Figure $2 d$ ).

The diorite and gabbro may be of different age, but the variation in direction between the two units is not significant with so few sites. The unit mean direction for the four sites from the diorite and gabbro is $D=067.4^{\circ}, I=-83.9^{\circ}$ (Table 2 and Figure $2 d$ ).

\section{Harrison Nunatak}

This locality consists of a coarse-grained homblendebearing gabbro. Difficulty of access and weather conditions prevented us from sampling more than one site (six samples). A K-Ar age of $\sim 121 \pm 6 \mathrm{Ma}$ was obtained from a very lowpotassium bearing hornblende separate. A single, stable upward directed to the northeast component of magnetization was observed in these specimens after AF demagnetization $(D=$ $50.3^{\circ}, I=-70.9^{\circ}$ ) (Tables 1 and 2and Figure $2 e$ ).

\section{Hale Glacier}

This outcrop consists of a pink, coarse-grained, biotitebearing granite cut by north-south trending mafic dikes. The exposure occurs on the eastern side of Hale glacier at the glacier's entrance onto the Abbot Ice Shelf. K-Ar dating on biotite yielded an age of $144 \pm 5 \mathrm{Ma}$ for the granite. While the granite sites were stable, the directions yielded were single component but in two orientations unrelated to the site or demagnetization history. The directions for component 1 are $D=244.7^{\circ}, I=-80.6^{\circ}$, while for component 2 the directions are $D=57^{\circ}, I=-73.2^{\circ}$ (Tables 1 and 2 and Figure $2 f$ ).

\section{Parker Peak}

Two sites, $\sim 5 \mathrm{~m}$ apart, were sampled within tilted, welllayered, andesitic crystal tuffs. A dolerite sill within the volcanics was dated at $144 \pm 3$ Ma using K-Ar whole rock (R.J. Pankhurst, personal commmunication, 1990). The volcanic rocks are fractured with epidotization occurring along the fracture surfaces. A single component of magnetization was observed in these rocks after AF demagnetization (Table 1 and Figure $2 g$ ). The mean directions for the 12 samples from the two sites are $D=114.4^{\circ}, I=-77.7^{\circ}$ before tilt correction and $D=$ $231.2^{\circ}, I=-48.3^{\circ}$ (Table 2 and Figure $2 g$ ). The age of magnetization for this location is unknown. The volcanic rocks are older than $144 \mathrm{Ma}$, but given the alteration within the rocks, it seems possible that they have been remagnetized.

\section{Shelton Head}

This locality consists of a pink, medium-grained granite with grey-green xenoliths of volcanic rocks and/or mafic dikes. The granite is cut by a set of east-northeast trending mafic dikes. Four sites were drilled, two in the mafic dikes and two in the granite. Age dating of the granite has been difficult; $\mathrm{Rb} / \mathrm{Sr}$ whole rock dating yields an age of $137 \pm 27 \mathrm{Ma}$, while K-Ar analysis yields on biotite an age of $\sim 152 \pm 2 \mathrm{Ma}$ and on hornblende an age of $142 \pm 5 \mathrm{Ma}$. The discrepancy in ages suggests disturbance in the isotopic system. The crosscutting dikes yield an age of $123 \pm 20 \mathrm{Ma}$.

The two granite sites produced two-component demagnetization trajectories (Table 1 and Figure $2 h$ ). The first component (A) is upward pointing to the east-southeast and occurs in the lower temperature part $\left(<530^{\circ} \mathrm{C}\right)$ of the demagnetization plot $\left(D=120.8^{\circ}, I=-73.8^{\circ}\right)$ (Table 2 and Figure $2 h$ ). The second component, $\mathrm{B}$, is downward pointing to the east $\left(D=103^{\circ}, I=78.5^{\circ}\right)$ and occurs between $530^{\circ} \mathrm{C}$ and $620^{\circ} \mathrm{C}$ (Table 2 and Figure $2 h$ ).

\section{Mount Simpson}

We were able to sample only one site (six samples) from this coarse-grained, pink granite because of weather conditions. By combining samples from Mount Simpson with the nearby Mount Noxom granite, an $\mathrm{Rb} / \mathrm{Sr}$ whole rock age of $145 \pm 2 \mathrm{Ma}$ was obtained [R.J. Pankhurst, personal communication, 1990].

A two-component magnetization was observed in these rocks after thermal demagnetization (Tables 1 and 2 and Figure 2i). A lower unblocking temperature component below $-500^{\circ} \mathrm{C}$ was generally upward pointing but variable in orientation and may represent a recent overprinting. The higher unblocking temperature component, isolated between $\sim 500^{\circ}$ to $620^{\circ} \mathrm{C}$, yielded consistent downward pointing west-southwest oriented directions of $D=264.6^{\circ}, I=74.8^{\circ}$ (Tables 1 and 2 Figure $2 i$ ).

\section{Landfall Peak}

Located at the westernmost end of Thurston Island, $50 \mathrm{~km}$ east of Mount Simpson, this medium-grained, hornblende + biotite-bearing diorite/granodiorite body is locally net veined by a grey, biotite-bearing granite which in tum is cut by granitic dikes of similar composition. The upper part of the nunatak appears to be an intrusion breccia with rafts of granitic and mafic material within a diroitic matrix. The main granodiorite body from the lower part of the nunatak yielded an ${ }^{40} \mathrm{Ar} /{ }^{39} \mathrm{Ar}$ biotite isochron age of $152 \pm 2 \mathrm{Ma}$. Six sites were drilled ( 40 cores). A site in the net-veined granite and a site in the diorite proved to be magnetically unstable. The remaining two sites within the granodiorite, one site in a diorite block surrounded by granitic net veining, and one site in a granite dike cutting the diorite yielded stable directions.

Like the Mount Simpson samples, the Landfall Peak granodiorite contains a two-component magnetization (Tables 1 and 2 and Figure $2 j$ ). A lower unblocking temperature component was generally upward pointing but varied in direction and did not produce well-grouped results. The higher temperature component yielded consistent downward pointing to the southwest directions (Tables 1 and 2 and Figure 2j). This high coercivity component $(30 \%$ of the magnetization remained after $100 \mathrm{mT}$ ) was defined between $570^{\circ} \mathrm{C}$ and $620^{\circ} \mathrm{C}$ 


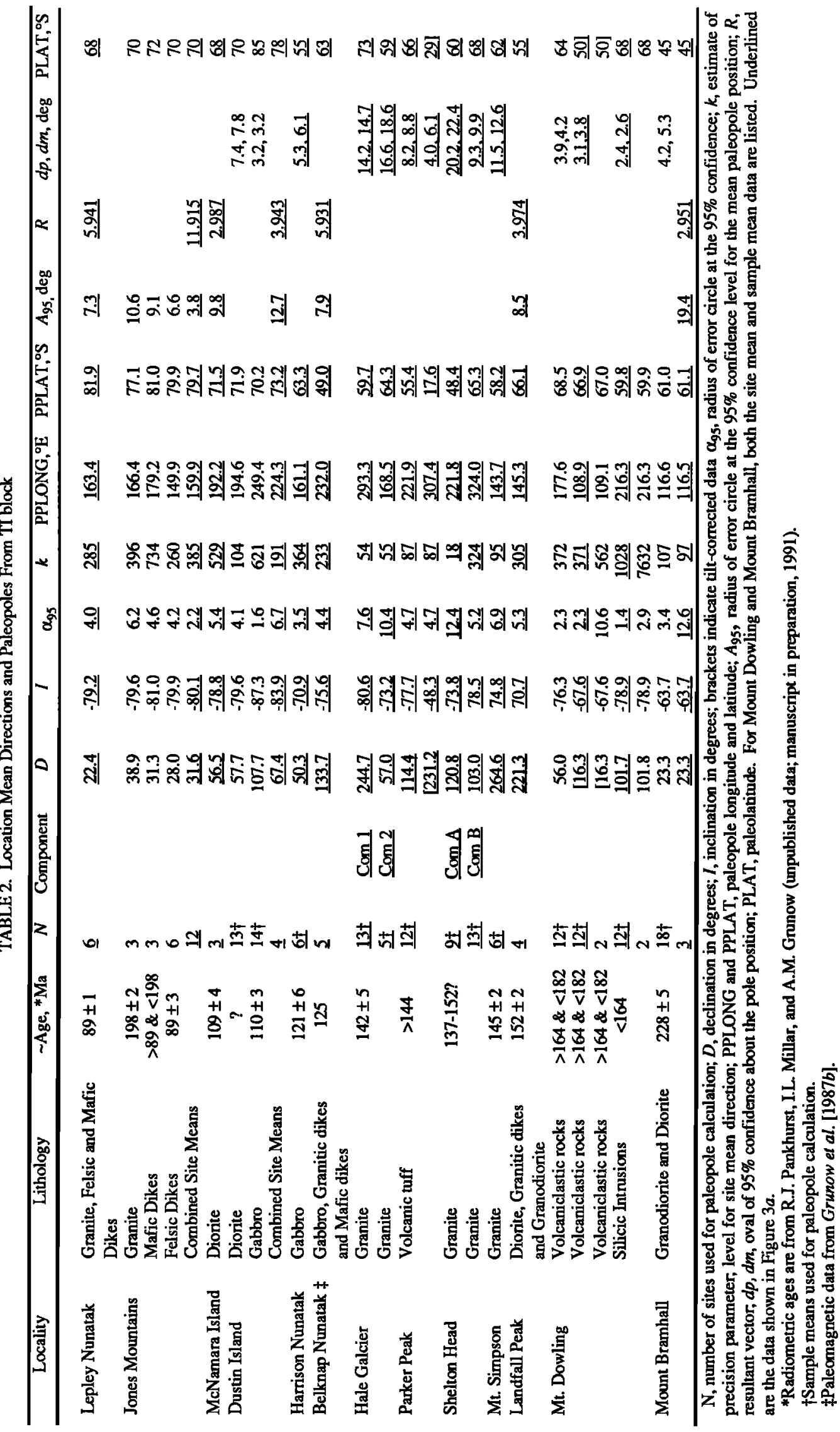


and given this high unblocking temperature $\left(T_{\mathrm{ub}}>585^{\circ} \mathrm{C}\right)$, we believe the carrier to be a titanohematite. The mean directions for Landfall Peak are $D=221.3^{\circ}, I=70.7^{\circ}$ (Table 2).

\section{Mount Dowling}

Gently dipping, thinly bedded, dark green to gray volcaniclastic rocks are cut by a northeast trending, 5-m-wide vertical feldspathic dike and a silicic intrusion at Mount Dowling. $\mathrm{Rb} / \mathrm{Sr}$ whole rock data suggest an age of at least $\sim 164$ $\pm 9 \mathrm{Ma}$ for the volcaniclastic rocks (R.J. Pankhurst, personal communication, 1990). Another outcrop visited by one member of the expedition proved to be a felsic intrusion which yielded an $\mathrm{Rb} / \mathrm{Sr}$ age of $182 \pm 2 \mathrm{Ma}$ and may be cogenetic with the volcaniclastic rocks (R.J. Pankhurst, personal communication, 1990). The dike and silicic intrusion have so far proved to be undatable. Three sites were drilled in the volcaniclastic rocks of which one was not magnetically stable, one site in a feldspathic dike and one site in the silicic intrusion for a total of 32 cores. The remaining two volcaniclastic sites were separated by $\sim 30 \mathrm{~m}$ of section and were located $\sim 20 \mathrm{~m}$ from the dike. Three volcaniclastic samples were collected adjacent to the intrusion for a baked contact test. A single, upward pointing east-southeast directed magnetization was observed from the feldspathic dike and intrusion $\left(D=101.8^{\circ}, I=-78.9^{\circ}\right.$ ) (Tables 1 and 2 and Figure $2 k$ ). The contact between the dike and the intrusion was not observed but it is likely that the dike originated from the intrusion and probably accounts for the high precision value.

The volcaniclastic rocks yielded upward pointing north to northeast directions $\left(D=56^{\circ}, I=-76.3\right)$ (Tables 1 and 2and Figure $2 k$ ). The samples collected adjacent to the intrusion for a baked contact test did not yield directions similar to the intrusion but did yield directions similar to the other sites within the volcaniclastic rocks (Figure $2 k$ ). Therefore we believe that the volcaniclastic rocks have not been remagnetized by the adjacent intrusion and were probably tilted during emplacement of the intrusion. We consider the age of magnetization to be $\sim 175 \mathrm{Ma}$ based on the $164 \mathrm{Ma}$ minimum age for the volcaniclastic rocks and the $182 \mathrm{Ma}$ age for the nearby felsic intrusion.

\section{Mount Bramhall}

Mount Bramhall consists of a medium-grained, hornblende + biotite-bearing granodiorite body with pods of finer-grained diorite schlieren. The ${ }^{40} \mathrm{Ar} /{ }^{39} \mathrm{Ar}$ analysis yielded a biotite isochron age of $\sim 228 \pm 5 \mathrm{Ma}$, while $\mathrm{K}-\mathrm{Ar}$ analysis on homblende yielded ages of $\sim 230 \mathrm{Ma}$. Two sites were drilled in the granodiorite and one in a diorite schlieren pod for a total of 18 cores. A single high-temperature component of magnetization (unblocking temperature to $670^{\circ} \mathrm{C}$ ) was observed in these rocks and is most likely deuterically formed hematite. The granodiorite sites yielded upward pointing, north-northeast directed vectors $\left(D=23.3^{\circ}, I=-63.7^{\circ}\right)$ (Tables 1 and 2 and Figure $2 l$ ). The diorite schlieren site yielded downward pointing, south-southwest directed vectors approximately antipodal to the granodiorite (Tables 1 and 2 and Figures $2 l$ ).

The granites sampled at Henderson Knob, Mount Noxom, and Long Glacier did not yield internally consistent results (Figure 1).

\section{INTERPRETATION OF TI BLOCK DATA}

All mean poles of the localities from the TI block are shown in Table 3 and Figure $3 a$. We have combined poles from several localities to produce time averaged poles at $\sim 90 \mathrm{Ma}, \sim 110 \mathrm{Ma}$, and $\sim 150 \mathrm{Ma}$ age for the TI block. The similarity in ages and paleopoles from the Jones Mountains and Lepley Nunatak (125 $\mathrm{km}$ to the east) allowed us to combine these two localities to give a $-90 \mathrm{Ma}$ TI paleopole of $161.4^{\circ} \mathrm{E}, 80.8^{\circ} \mathrm{S}, A_{95}=3.9^{\circ}, N=$ 18 VGPs (Table 3 and Figure $3 b$ ). This pole is significantly different from the pole obtained from Tertiary volcanic rocks in the Jones Mountains and Hudson Mountains by Scharnberger and Sharon [1972].

We have chosen to combine the Dustin Island and McNamara Island VGPs because the radiometric ages overlap to yield a $\sim 110 \mathrm{Ma}$ pole of $209.8^{\circ} \mathrm{E}, 73.1^{\circ} \mathrm{S}, A_{95}=7.6^{\circ}, K=64$ for $N=7$ VGPs (Table 3 and Figures $3 a$ and $3 b$ ). The Harrison Nunatak (121 Ma) VGP is different from both the $\sim 110 \mathrm{Ma}$ pole and the -125 Ma pole (from Belknap Nunatak, Table 3) and has not been used because we believe that either secular variation has not been averaged out the rocks have been tilted or the age does not reflect the time of magnetization. Argon loss in homblende is not uncommon and combined with the very low potassium content of the mineral separate upon which the age is based (0.1\%; R.J. Pankhurst (personal communication, 1990)), we feel that the radiometric age may not be reflecting the age of magnetization.

The VGPs from Landfail Peak and Mount Simpson produced a $\sim 150 \mathrm{Ma}$ pole of $144.9^{\circ} \mathrm{E}, 64.5^{\circ} \mathrm{S}, A_{95}=7.0^{\circ}, K=122, N=5$ VGPs (Table 3 and Figures $3 a$ and $3 b$ ). We believe that the reversed polarity magnetization was acquired prior to the Cretaceous normal polarity interval since the data give paleolatitudes too low for a Late Cretaceous to Tertiary position and are not similar to the Late Cretaceous to Tertiary AP or East Antarctic reference poles [Watts, 1982; Watts et al., 1984]. We have not used the Hale Glacier (145 Ma) results because of the lack of within site precision and the uncertainty in the origin of two different single-component magnetizations within a site. It is interesting to note that component 2 from Hale Glacier is not disimilar to the $\sim 150 \mathrm{Ma}$ poles and very similar to Harrison Nunatak (Table 2 and Figure $3 a)$.

The baked contact test at Mount Dowling suggests that the volcaniclastic rocks were not remagnetized by the silicic intrusions. We consider the single-component directions to be primary and have applied the tilt correction because it is likely that these fine-grained volcaniclastic rocks were deposited near the horizontal datum. The coincidence of $\mathrm{K}-\mathrm{Ar}$ (and Ar/Ar) ages in hornblende and biotite at Mount Bramhall (230 Ma) suggests that these rocks did not experience a prolonged cooling history and have not been reheated beyond the closure temperature of biotite $\left(-300^{\circ} \mathrm{C}\right)$. This combined with the high unblocking temperature of the magnetic minerals, the singlecomponent nature of the magnetization, and the normal and reversed polarity directions suggest that the magnetization is primary. The similarity of the $230 \mathrm{Ma}$ and $175 \mathrm{Ma}$ TI poles (Table 3 and Figures $3 a$ and $3 b$ ) suggests that the TI block experienced little apparent polar wander.

The Shelton Head component B and Hale Glacier component 1 results are not like any of our other results from Thurston Island and could be reflecting remagnetization (Table 2 and Figure $3 a$ ). The close similarity of Shelton Head component $A$ with our results from Belknap Nunatak (125 Ma) may reflect remagnetization in the Early Cretaceous caused by the igneous event that produced the $\sim 123 \mathrm{Ma}$ Shelton Head dikes. The Parker Peak paleopole without tilt correction is similar to those from Belknap Nunatak, Shelton Head component A, and the Mount Dowling dikes (Figure 3a). The Mount Dowling dike 
a.

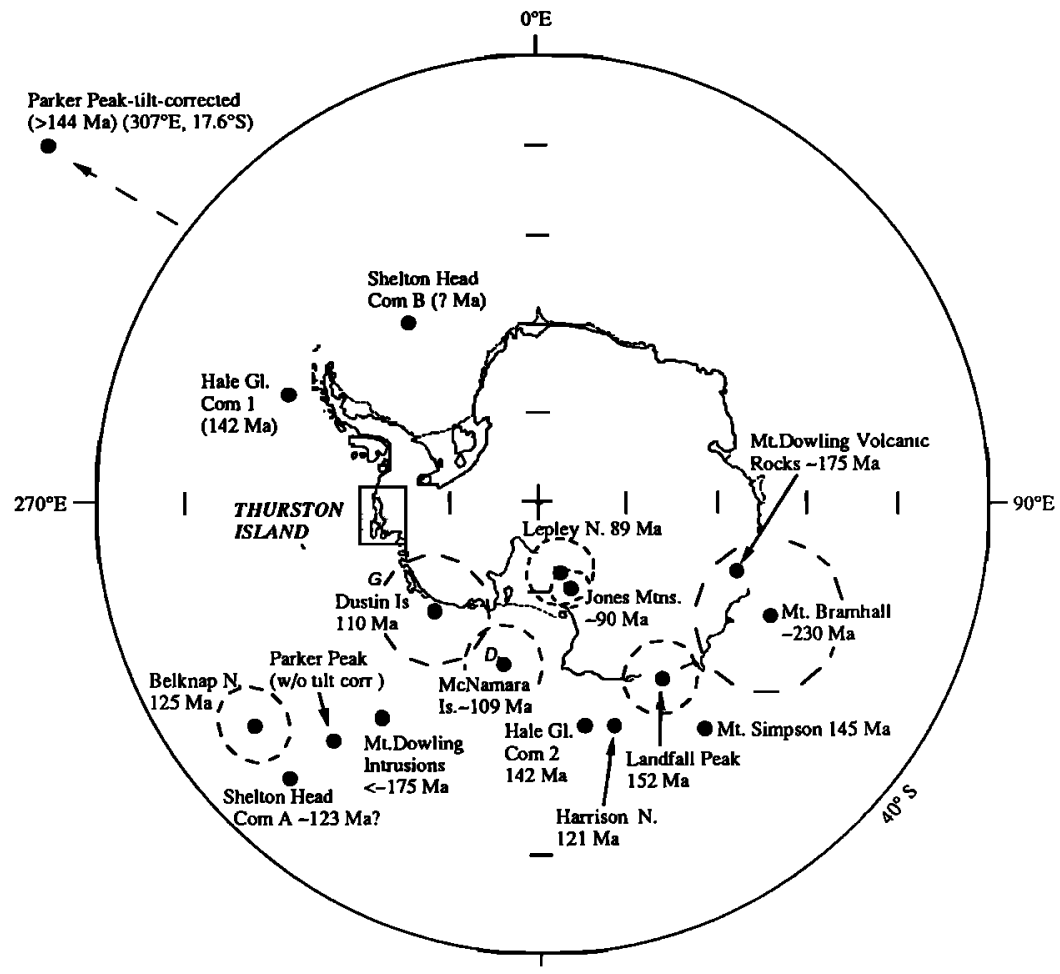

b.

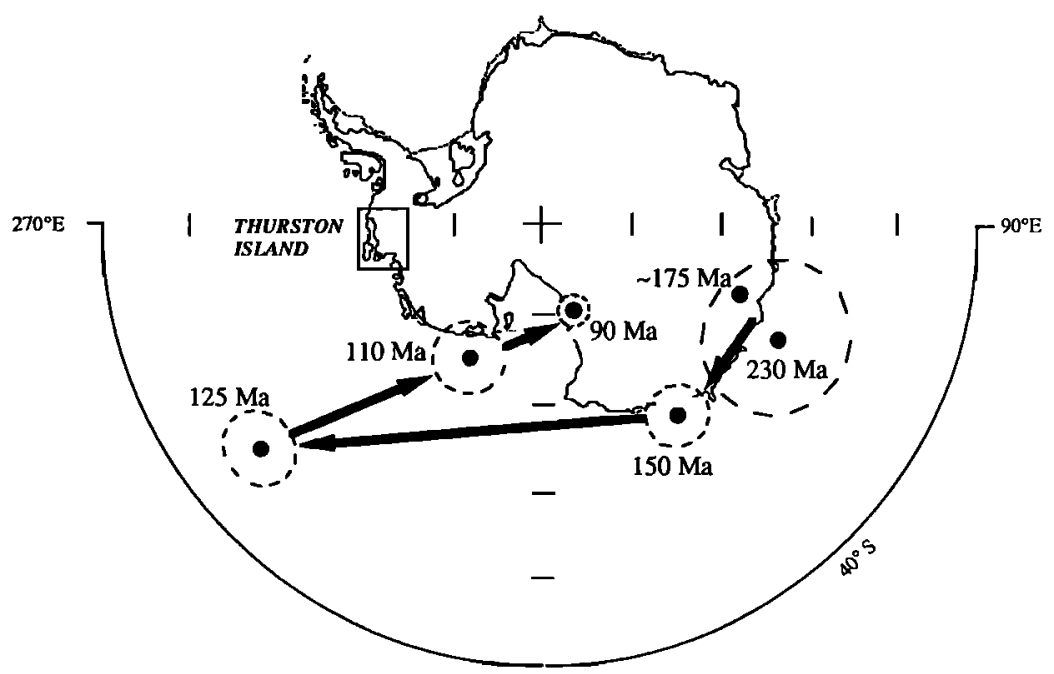

Fig. 3. (a) Equal-angle projection of TI poles with their respective A63s (except for Hale Glacier, Harrison Nunatak, Mount Simpson, and Shelton Head where the data are too few). D and G, Dustin Island diorite and gabbro. Poles are from Table 2. (b) TI apparent polar wander path (with A63s); see Table 3.

TABLE 3. TI Paleopoles for TI Apparent Polar Wander Path

\begin{tabular}{cccccl}
\hline Age, Ma & Longitude ${ }^{\circ} \mathrm{E}$ & Latitude $^{\circ} \mathrm{S}$ & $A_{95}, \mathrm{deg}$ & $A_{63}, \mathrm{deg}$ & \multicolumn{1}{c}{ Basis for Poles } \\
\hline$\sim 230$ & 116 & 61 & 19.4 & 8.4 & $N=3$ site mean VGPs from Mount Bramhall \\
$\sim 175$ & 109 & 67 & - & - & $N=2$ site mean VGPs from Mount Dowling \\
$\sim 150$ & 145 & 64 & 7 & 3.5 & $N=5$ site mean VGPs from Landfall Park (4); Mount Simpson (1) \\
$\sim 125$ & 232 & 49 & 7.9 & 4.1 & $N=5$ site mean VGPs from Belknap Nunatak \\
$\sim 110$ & 210 & 73 & 7.6 & 4.0 & $N=7$ site mean VGPs from Dustin Island (4); McNamara Island (3) \\
$\sim 90$ & 161 & 80 & 3.9 & 1.7 & $N=18$ site mean VGPs from Lepley Nunatak (6); Jones Mountains (12) \\
\hline
\end{tabular}

and intrusion pole lie between the 150-125 $\mathrm{Ma}$ and 125-100 Ma TI poles; therefore we consider it possible that the age of magnetization for these rocks is between $150 \mathrm{Ma}$ and $100 \mathrm{Ma}$ (Figure 3a). The similarity of the Shelton Head, Parker Peak, and Mount Dowling intrusion poles with Belknap Nunatak indicates that our previous results were not anomalous.
However, these data are not used in the reconstructions given the uncertainty in the age of magnetization.

Although we cannot eliminate the possibility of tilting for these data, we believe that the similarity of paleomagnetic poles obtained from various rock types of equivalent age over a large region argues against significant tilting of small blocks. 
TABLE 4. Mean Paleopoles (With Their $A_{95}$ ) used in the tectonic reconstructions

\begin{tabular}{cllcc}
\hline Age, Ma & \multicolumn{1}{c}{ East Antarctica* } & \multicolumn{1}{c}{ TI } & \multicolumn{1}{c}{ AP } & EWM \\
\hline$\sim 230$ & $225^{\circ}, 54^{\circ}\left(11^{\circ}\right)$ Af & $116^{\circ}, 61^{\circ}\left(19.4^{\circ}\right)$ & & Meferences \\
$\sim 175$ & $220^{\circ}, 55^{\circ}\left(3.9^{\circ}\right)$ & $109^{\circ}, 67^{\circ}(--)$ & $237^{\circ}, 46^{\circ}\left(6.4^{\circ}\right)$ & $235^{\circ}, 41^{\circ}\left(5.3^{\circ}\right)$ \\
$\sim 150$ & $201^{\circ}, 69^{\circ}\left(13^{\circ}\right)$ S.Am & $145^{\circ}, 64^{\circ}\left(7^{\circ}\right)$ & & $2,3,4$ \\
$\sim 125$ & $202^{\circ}, 72^{\circ}\left(11^{\circ}\right)$ Af & $232^{\circ}, 49^{\circ}\left(7.9^{\circ}\right)$ & & 1,2 \\
-110 & $194^{\circ}, 72^{\circ}\left(13^{\circ}\right)$ Aus & $210^{\circ}, 73^{\circ}\left(7.6^{\circ}\right)$ & $195^{\circ}, 65^{\circ}\left(9^{\circ}\right)$ & 5 \\
$\sim 90-95$ & $204^{\circ}, 76^{\circ}\left(12^{\circ}\right)$ Aus & $161^{\circ}, 80^{\circ}\left(3.9^{\circ}\right)$ & $132^{\circ}, 77^{\circ}\left(10^{\circ}\right)$ & $1,2,6$ \\
\hline
\end{tabular}

References: 1, Irving and Irving [1982]; 2, this paper, see Table 3; 3, Longshaw and Griffiths [1983]; 4, Grunow et al. [1987a; 5, Grunow et al. [1987b]; 6, Kellogg and Rowly [1989]; 7, Watts et al. [1984]; 8, Grindley and Oliver [1983].

*The Gondwanaland reference poles (Af, Africa; S.Am, South America; Aus, Australia) have been rotated to East Antarctica using the Norton and Sclater [1979] rotation poles.
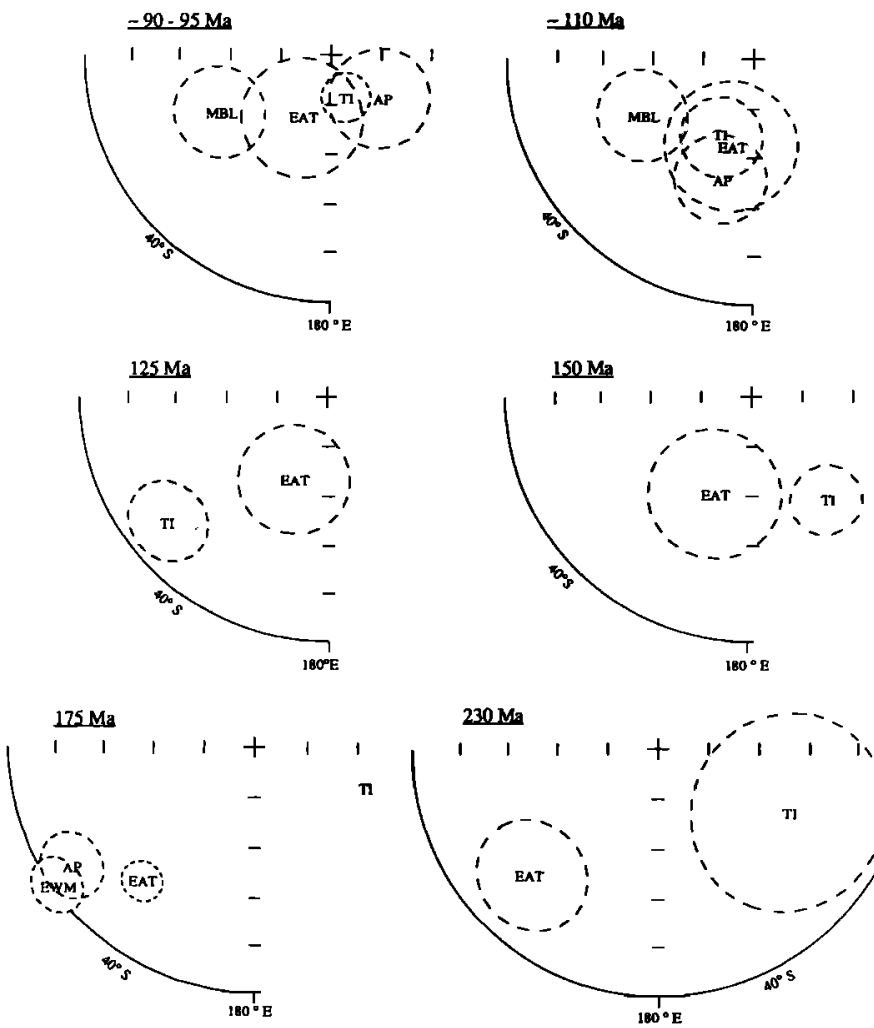

Fig. 4. Equal-angle projection of paleomagnetic poles (with their A95s) from the West Antarctic crustal blocks (AP, TI, EWM, MBL) and East Antarctica (EAT) for each time period; see Table 4.

The flat-lying Tertiary volcanic rocks in the Jones Mountains indicate that there has been no tilting here since the Oligocene. The similarity of poles of mid-Cretaceous and younger age from TI with those of equivalent age from the AP and East Antarctica suggests to us that little tectonic tilting on any scale has occurred since at least mid-Cretaceous time (Table 4 and Figure 4). Last, few faults or shear zones were observed at the locations discussed in this paper, although it should be emphasized that many exposures were of limited extent.

\section{Comparison of Paleomagnetic RefFerence Poles}

The paleomagnetic poles from the West Antarctic crustal blocks and East Antarctica are shown in Table 4 and Figure 4. Apart from the $175 \mathrm{Ma}$ East Antarctic reference pole [Grunow et $a l ., 1987 a]$, there are no other well-established Mesozoic reference poles from East Antarctica. Therefore, for the other relevant time periods we have used reference poles from Africa at $230 \mathrm{Ma}$ [Irving and Irving, 1982], South America at $150 \mathrm{Ma}$ [Irving and Irving, 1982], Africa at $\sim 120 \mathrm{Ma}$ [Grunow et al., $1987 \mathrm{~b}$ ], Australia at $110 \mathrm{Ma}$ [Irving and Irving, 1982], and
Australia at $-90 \mathrm{Ma}$ [Irving and lrving, 1982] rotated into an East Antarctic reference frame using the Norton and Sclater [1979] rotation parameters (Table 4 and Figure 4).

We did not use the mean $150 \mathrm{Ma}$ pole from Africa [Irving and lrving, 1982] because it is primarily based on poles from Morocco where the Cretaceous mobile zone associated with creation of the Atlas Mountains may have disturbed them. The $120 \mathrm{Ma}$ pole from Grunow et al. [1987b] is based on the African poles listed by Irving and Irving but without the Morrocan pole for the reason stated above. The $\sim 120$ Ma pole listed by Besse and Courtillot [1988] is very similar to the Grunow et al. pole when rotated to East Antarctica.

Paleomagnetic poles from the other West Antarctic crustal blocks used in the tectonic models include the $175 \mathrm{Ma}$ pole from the AP and EWM blocks [Longshaw and Griffiths, 1983; Grunow et al., 1987a], the $\sim 110$ Ma pole from the AP block [Kellogg and Rowley, 1989], the $-90-110 \mathrm{Ma}$ pole from the MBL block [Grindley and Oliver, 1983], and the 90-95 Ma pole from the AP block [Watts et al., 1984] (Table 4 and Figure 4).

\section{RECONSTRUCTIONS}

The pre- and post-Gondwanaland breakup rotation poles of Norton and Sclater [1979] have been used in the reconstructions for the major continents. The rotation poles used to restore the West Antarctic crustal blocks and the Falkland Islands (FI) [Taylor and Shaw, 1989] are listed in Table 5. For simplicity, the present continental outlines and subice topography have been used to define the crustal blocks in the reconstructions, the exact configuration of these blocks prior to Cenozoic time being unknown. The East Antarctic reference pole is used as the geographic south pole in the figures. The Precambrian gneisses from the Haag Nunataks [Millar and Pankhurst, 1987] are considered to be part of the EWM block. For lack of other data, the MBL block is left in its 90-95 Ma position based on the data of Grindley and Oliver [1983] for the older reconstructions (Table 5). The major events in the evolution of the West Antarctic blocks, East Antarctica, and the southern ocean basins between $\sim 230 \mathrm{Ma}$ and $-90 \mathrm{Ma}$ are outlined in Table 6 .

\section{TECTONIC MODELS}

\section{$230 \mathrm{Ma}$}

The $230 \mathrm{Ma}$ reconstruction is based on the Mount Bramhall pole (Figure $5 a$ ). The position shown for the TI block in this reconstruction creates an opening along the Pacific convergent margin between TI and MBL. No data exist for the AP block at $230 \mathrm{Ma}$, and therefore we leave it in its $175 \mathrm{Ma}$ position. We believe that the $90^{\circ}$ counterclockwise rotation of the EWM block predicted from Cambrian paleomagnetic data [Watts and 
TABLE 5. Rotation Poles Relative to East Antarctica

\begin{tabular}{|c|c|c|c|c|}
\hline Plate & Time, Ma & Longitude $^{\circ}$ & Latitude $^{\circ}$ & Angle, deg \\
\hline \multirow[t]{6}{*}{ Thurston Island } & 230 & 88.22 & 78.16 & 102.47 \\
\hline & 175 & 86.14 & 74.23 & 79.96 \\
\hline & 150 & 91.64 & 79.72 & 35.68 \\
\hline & 125 & -72.94 & -61.10 & 29.64 \\
\hline & 110 & -179.54 & 85.33 & -5.40 \\
\hline & 90 & 0.00 & 0.00 & 0.00 \\
\hline \multirow[t]{6}{*}{ Antarctic Peninsula } & 230 & -79.50 & -70.02 & 51.89 \\
\hline & 175 & -93.20 & -72.30 & 35.48 \\
\hline & 150 & -94.73 & -67.32 & 27.23 \\
\hline & 125 & -72.94 & -61.01 & 29.64 \\
\hline & 110 & 0.00 & 90.00 & -1.81 \\
\hline & 90 & 0.00 & 0.00 & 0.00 \\
\hline \multirow[t]{5}{*}{ Ellsworth-Whitmore Mountains } & 230 & -27.54 & -84.05 & -79.07 \\
\hline & 175 & -88.10 & -62.14 & 35.37 \\
\hline & 150 & -88.86 & -62.17 & 33.69 \\
\hline & 125 & -81.65 & -62.59 & 34.14 \\
\hline & 90 & 0.00 & 0.00 & 0.00 \\
\hline \multirow[t]{4}{*}{ Marie Byrd Land } & 230 & 18.55 & 61.91 & 22.28 \\
\hline & 175 & 34.84 & 53.63 & 12.54 \\
\hline & 90 & 34.84 & 53.63 & 12.54 \\
\hline & 40 & 0.00 & 0.00 & 0.00 \\
\hline \multirow{2}{*}{$\begin{array}{l}\text { Falkland/Malvinas Islands } \\
\text { (fixed to Africa) }\end{array}$} & 230 & 169.20 & 45.30 & -156.25 \\
\hline & 175 & -33.40 & 47.40 & 55.77 \\
\hline
\end{tabular}

Bramall, 1981; Grunow et al., 1987a] and geologic data [Schopf, 1969; Dalziel and Elliot, 1982] occurred between the Permo-Triassic Gondwanide Orogeny and the emplacement of the 175 Ma granites in the EWM block [Millar and Pankhurst, 1987] from which the EWM 175 Ma pole is based [Grunow et al., 1987a, b] (Table 6). A proposed $120^{\circ}$ clockwise rotation of the Falkland Islands (FI) occurred between Early Jurassic and the opening of the South Atlantic [Taylor and Shaw, 1989]. Therefore, in the reconstructions, we have shown the EWM and FI in a prerotation position at $230 \mathrm{Ma}$ and in a postrotation position at $175 \mathrm{Ma}$.

The EWM and FI rotations may have been caused by early extension and associated transcurrent motion during the early breakup of the supercontinent [Dalziel et al., 1987; Taylor and Shaw, 1989; Dalziel and Grunow, in press]. Early Jurassic mafic lavas found in Dronning Maud Land [Lфvlie, 1979] could be indicating early extension along this margin. Early Mesozoic strike-slip shear zones have been documented in Patagonia [Rapela, et al., 1989] providing additional evidence that major transcurrent motion occurred just after the Gondwanide Orogeny and prior to the main phase of Gondwanaland breakup (Table 6) [Rapela et al., 1989].

\section{$175 \mathrm{Ma}$}

The $175 \mathrm{Ma}$ reconstruction is based on the AP and EWM 175 $\mathrm{Ma}$ poles [Longshaw and Griffiths, 1983; Grunow et al., 1987a] (Figure 5b). Minor counterclockwise rotation of the AP and EWM blocks is required to restore these poles to the 175 Ma East Antarctic pole. We have speculatively shown an extensional basin between the AP-TI and EWM blocks and between EWM and East Antarctica which coincides with the present location of the Byrd subglacial basin (BSB) and Explora Wedge (EW), respectively (Table 6 and Figure $5 b$ ). Extension of such basins along the Transantarctic Mountains is consistent with structural data from this region [Wilson, 1991] and the location of Middle Jurassic extension related igneous rocks in southem South America and the AP block [Dalziel et al., 1987]. This reconstruction would also suggest that the TI coast line parallel to the present trend of Pine Island Bay (Figure 1, inset) was once along the Pacific convergent margin (Figures $5 a$ and $5 b$ ).
The FI block is shown after a $155^{\circ}$ clockwise rotation in two positions: its present day position with respect to South America and in a position near Africa (Figure $5 b$ ). An estimated $\sim 400 \mathrm{~km}$ of Middle to Late Jurassic east-west directed extension in the Falkland Plateau area [Lorenzo and Mutter, 1988] may have moved the FI block westward to its present day position with respect to South America.

\section{$\sim 150 \mathrm{Ma}$}

Based on comparison of the $150 \mathrm{Ma}$ East Antarctic and TI pole means, counterclockwise rotation of the TI block is predicted between $\geq 150 \mathrm{Ma}$ and $\sim 125 \mathrm{Ma}$ (Tables 4 and 5 and Figure 5c). The TI rotation probably started with creation of the first sea-floor (M25 which is $156 \mathrm{Ma}$ using the Decade of North American Geology (DNAG) time scale [Palmer, 1983]) in the Mozambique-Somali basins [Simpson et al., 1979; Segoufin and Patriat, 1980; Rabinowitz et al., 1983] and ceased with opening of the South Atlantic Ocean basin at $\sim 130 \mathrm{Ma}$ (M10) [Rabinowitz and LaBrecque, 1979] (Table 6). This spreading system was connected to the southeastern Weddell Sea along the Explora Escarpment [Lawver et al., 1991] and presumably to the southwestern Weddell Sea basin and Rocas Verdes basin in South America [Dalziel, 1981; Mukasa et al., 1988] (Figure 5c). Upper Jurassic to Lower Cretaceous back arc basin sedimentary deposits found along the eastern side of the Antarctic Peninsula provide geologic evidence for existence of a submarine basin in the westem Weddell Sea area [Suarez, 1976; Thomson, 1982; Kellogg and Rowley, 1989]. Geosat data reveal northeast directed lineaments in the southwestern Weddell Sea Basin record opening behind the AP block [Bell, 1989] (Figure 5c). The Geosat data also reveal a series of presently east-northeast trending lineaments in the southeastern Weddell Sea basin interpreted as fracture zones that record east-northeast directed Late Jurassic-Early Cretaceous extension [Bell, 1989; Bell et al., 1990] related to the Mozambique basin opening.

The southward motion of an EWM block connected to East Antarctica during opening of the Mozambique basin may have caused the counterclockwise rotation of the TI block and transpressional deformation, known as the Palmer Land deformational event, in the southern AP block [Kellogg and 


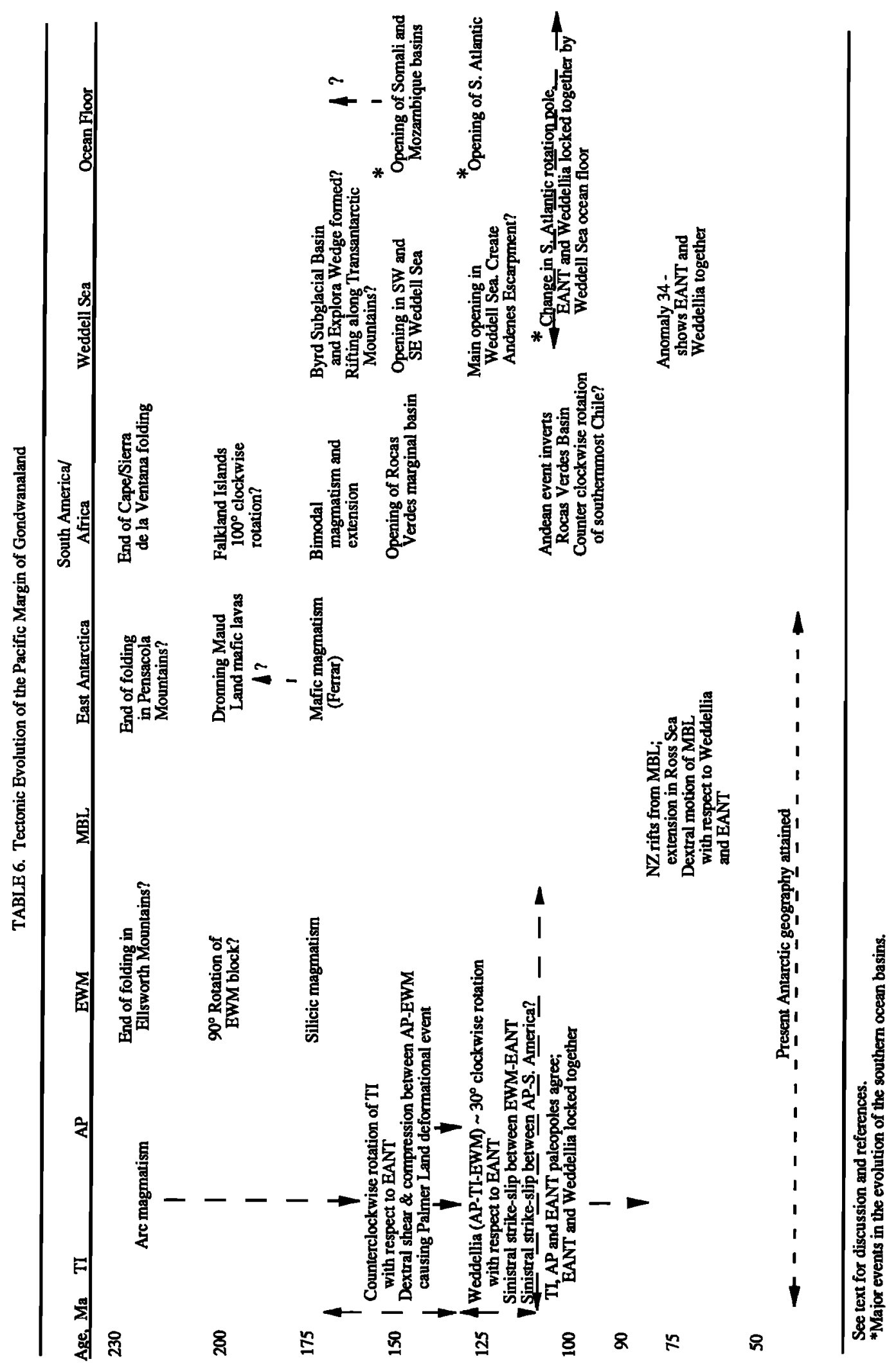




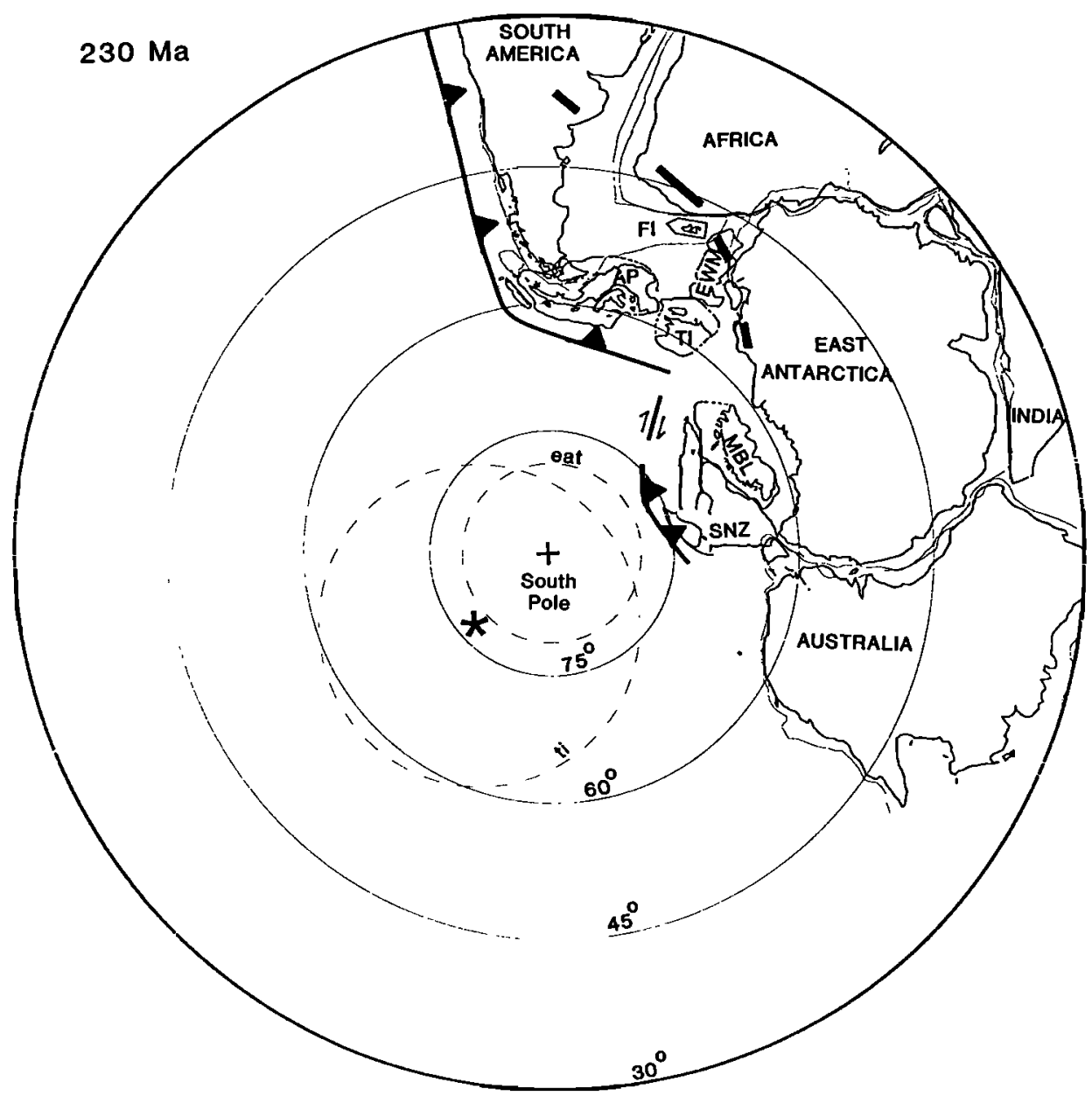

Fig. 5a. Reconstruction for $230 \mathrm{Ma}$. In all of the reconstructions, the geographic south pole ( + ) is centered on the East Antarctic (eat) reference pole; the West Antarctic paleopoles are located with asterisks. For simplicity, the present continental outlines and sub-ice topography have been used to define the crustal blocks. The FI block is pointed on one side to better display its rotation and is not meant to reflect its configuration in the Mesozoic. Abbreviations are as follow: AP, Antarctic Peninsula; ap, AP block $A_{95}$ circle; BSB, Byrd Subglacial Basin; EW, Explora Wedge; EWM, Ellsworth-Whitmore Mountains; ewm, EWM block $A_{95}$ circle; MAD, Madagascar, MB, Mozambique Basin; MBL, Marie Byrd Land; mbl, MBL block paleopole; SB, Somali Basin; SNZ, South Island New Zealand; PIB, Pine Island Bay; PL, Palmer Land; RVB, Rocas Verdes Basin; TI, Thurston Island; ti, TI block $A_{95}$ circle. At $230 \mathrm{Ma}$, approximately $-90^{\circ}$ of TI clockwise rotation is needed to restore the TI pole to the East Antarctic one. The EWM and FI blocks are shown in their prerotation positions. The AP and MBL blocks are left in their $175 \mathrm{Ma}$ and 100 Ma positions, respectively. The bold lines mark the location of the Gondwanide fold belts in South America, Africa, the FI block, the EWM block and East Antarctica.

Rowley, 1989] (Table 6 and Figure 5c). We show a RFF triple junction in the southwestem Weddell Sea basin with a faster relative rate of opening in the eastern versus western Weddell Sea basin to account for dextral shearing (Figure $5 c$ ). The presumed tectonic boundary between the AP and TI blocks may have been located at the base of the AP block in what is called the Ellsworth Fault System (EFS) [Kellogg and Rowley, 1989]. Movement along the EFS is thought to have been in the Late Cretaceous or Tertiary [Kellogg and Rowley, 1989] but based on the new TI paleomagnetic data, the EFS may have also been active in the Jurassic and Early Cretaceous. The TI block rotation may also have been caused by strike-slip associated with the Pacific convergent margin, like that observed in the Andes [Beck, 1989; Cunningham et al., 1991]. The EWM block may not have escaped deformation along this transpressional zone because the margins of the EWM block record an unusual second structural fabric [Storey and Dalziel, 1987] that we have related to shearing of the EWM against both the Antarctic Peninsula and East Antarctica [Grunow et al., 1987b] (Table 6).

\section{$\sim 130 \mathrm{Ma}$}

The two-plate rifting system between East and West Gondwanaland (the AP block constitutes a third small plate prior to $130 \mathrm{Ma}$ ) became a three-plate system with the start of South Atlantic opening [Lawver et al., 1991]. We propose that this change to a three-plate system affected the movement history of the AP, TI, and EWM blocks such that the EWM block became connected to the AP-TI blocks creating a fourth minor plate that we refer to as Weddellia. A $\sim 30^{\circ}$ clockwise rotation of Weddellia with respect to East Antarctica is required between $\sim 125 \mathrm{Ma}$ and $\sim 100 \mathrm{Ma}$ based on our results from Belknap Nunatak (Tables 4 and 5 and Figure 5d) [Grunow et al., $1987 b]$. This would produce sinistral shear of $\sim 750 \mathrm{~km}$ between the EWM block and East Antarctica which is significantly less than what we proposed earlier [Grunow et al., 1987b] because in this model the EWM block remained attached to East Antarctica between $150 \mathrm{Ma}$ and $130 \mathrm{Ma}$. Inferred Cenozoic extension within the EWM block [Garrett et al., 1987] may explain the overlap of the EWM block with the AP and TI 


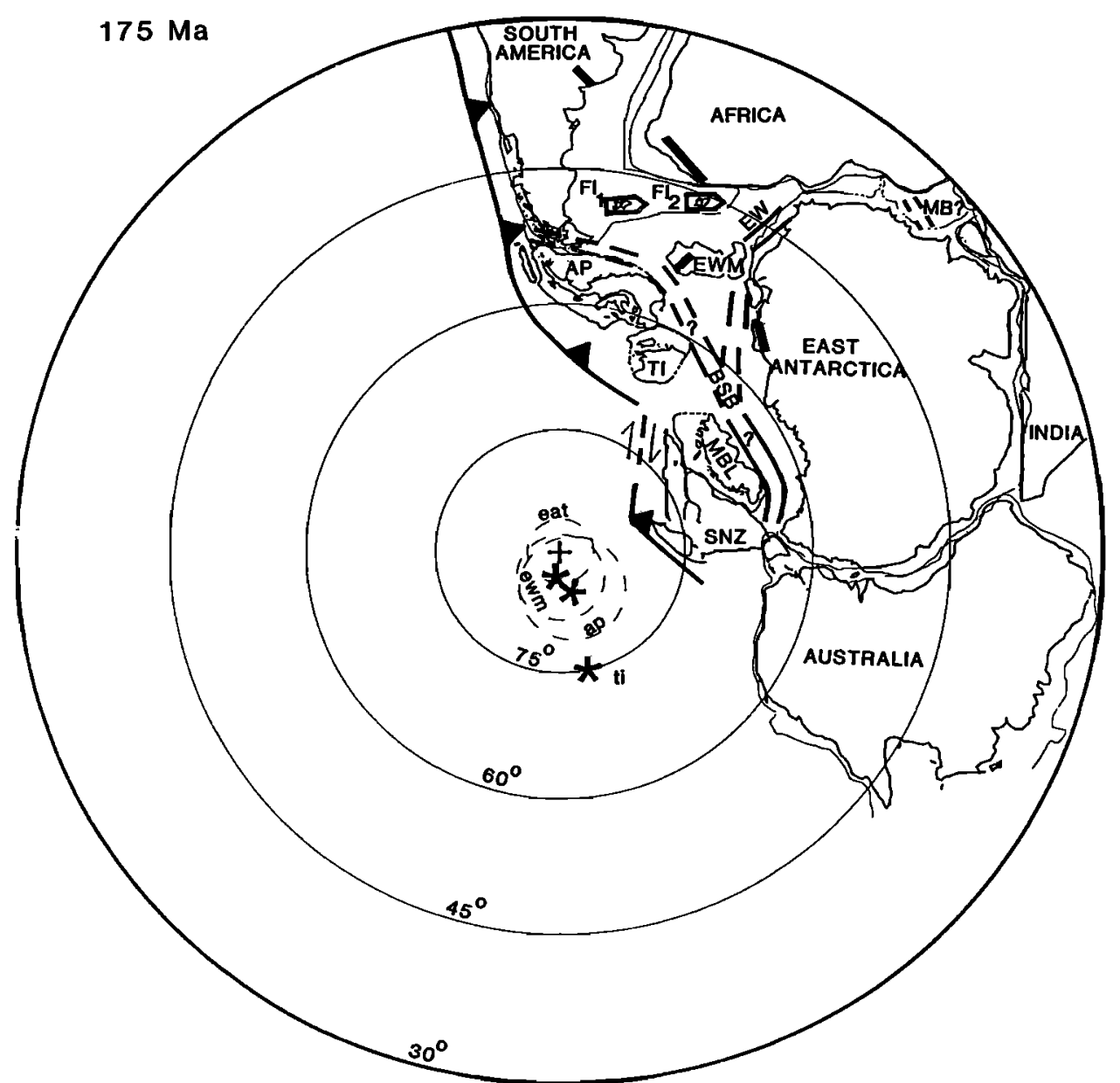

Fig. 5b. Reconstruction for $175 \mathrm{Ma}$; caption same as Figure 5a. The TI, AP, and EWM blocks have been shown using the individual AP, TI, and EWM poles. The EWM block has rotated $-90^{\circ}$ between $230 \mathrm{Ma}$ and $175 \mathrm{Ma}$. The FI block is shown after a $-155^{\circ}$ rotation in both a present-day position with respect to South America (FI 1) and in a position adjacent to Africa (FI 2). The location of the TI $\sim 175$ Ma? paleopole (ti) is also shown. Speculatively shown are possible rift basins: the Byrd Subglacial Basin (BSB); the Explora Wedge (EW) and rifting along the Transantarctic Mountains and extension within southem South America and on the eastem (backarc) side of the AP block.

blocks. A RFF triple junction could explain this shear motion (Figure 5d) while the RRR triple junction connects the opening in the Weddell Sea to that in the South Atlantic and southwest Indian oceans [Lawver et al., 1991]. The relative rate of opening in the Weddell Sea would have to have been faster than in the SE Indian. Ocean to account for sinistral shearing between the EWM and East Antarctica. The NE trending lineaments in the GEOSAT data [Bell, 1989; Bell et al., 1990] found adjacent to the Antarctic Peninsula and across most of the Weddell Sea reflect northeast directed extension that provided the mechanism for the clockwise rotation of Weddellia.

Upper Jurassic to Lower Cretaceous sedimentary rocks in the northern AP block experienced Early Cretaceous strike-slip deformation [Whitham and Storey, 1989]. Initiation of spreading in the South Atlantic ocean basin may have resulted in a cessation of spreading in the Rocas Verdes basin and initiation of a strike-slip setting in southernmost South America and the northernmost Antarctic Peninsula (Figure 5d). There could also have been continued dextral strike-slip motion between the EWM block and the base of the AP block between $\sim 125 \mathrm{Ma}$ and $\sim 100 \mathrm{Ma}$ given that deformation is thought to have continued in the southeastern AP block until at least the Albian [Meneilly et al., 1987]. The Weddellia Early Cretaceous clockwise rotation may have been transferred to the Pacific convergent margin along a strike-slip zone in the Pine
Island Bay area (Figure 5d). If MBL was near the Transantarctic Mountains during this time period, then sinistral motion is required between MBL and Weddellia as Weddellia rotated into its present day position with respect to East Antarctica.

A model proposed by Kristofferson and Haugland [1986] suggested that Weddellia was locked to East Antarctica by the Middle to Late Jurassic on the basis of interpreting the Andenes and Explora Escarpments as the same rift structure (Figure 1). Lawver et al. [1991] consider the Andenes Escarpment to be related to opening of the central Weddell Sea basin that began with the opening of the South Atlantic basin $130 \mathrm{Ma}$; its alignment with the Explora Escarpment is coincidental. They also suggest that Weddellia was locked to East Antarctica when the opening in the South Atlantic ocean basin began, but clear identification of magnetic anomalies that definitively tie East Antarctica to Weddellia have not been documented: Controversy still occurs over the identification of magnetic anomalies in the Weddell Sea; the M29. ( 160 Ma) anomaly identified by LaBrecque and Barker [1981] is thought to be M10 ( $130 \mathrm{Ma}$ ) by Martin and Hartnady [1986], coincident with opening in the South Atlantic ocean basin.

\section{$\sim 110-90 \mathrm{Ma}$}

Weddellia appears to have been in or near its present-day position with respect to East Antarctica by $\sim 110 \mathrm{Ma}$ (Figure 


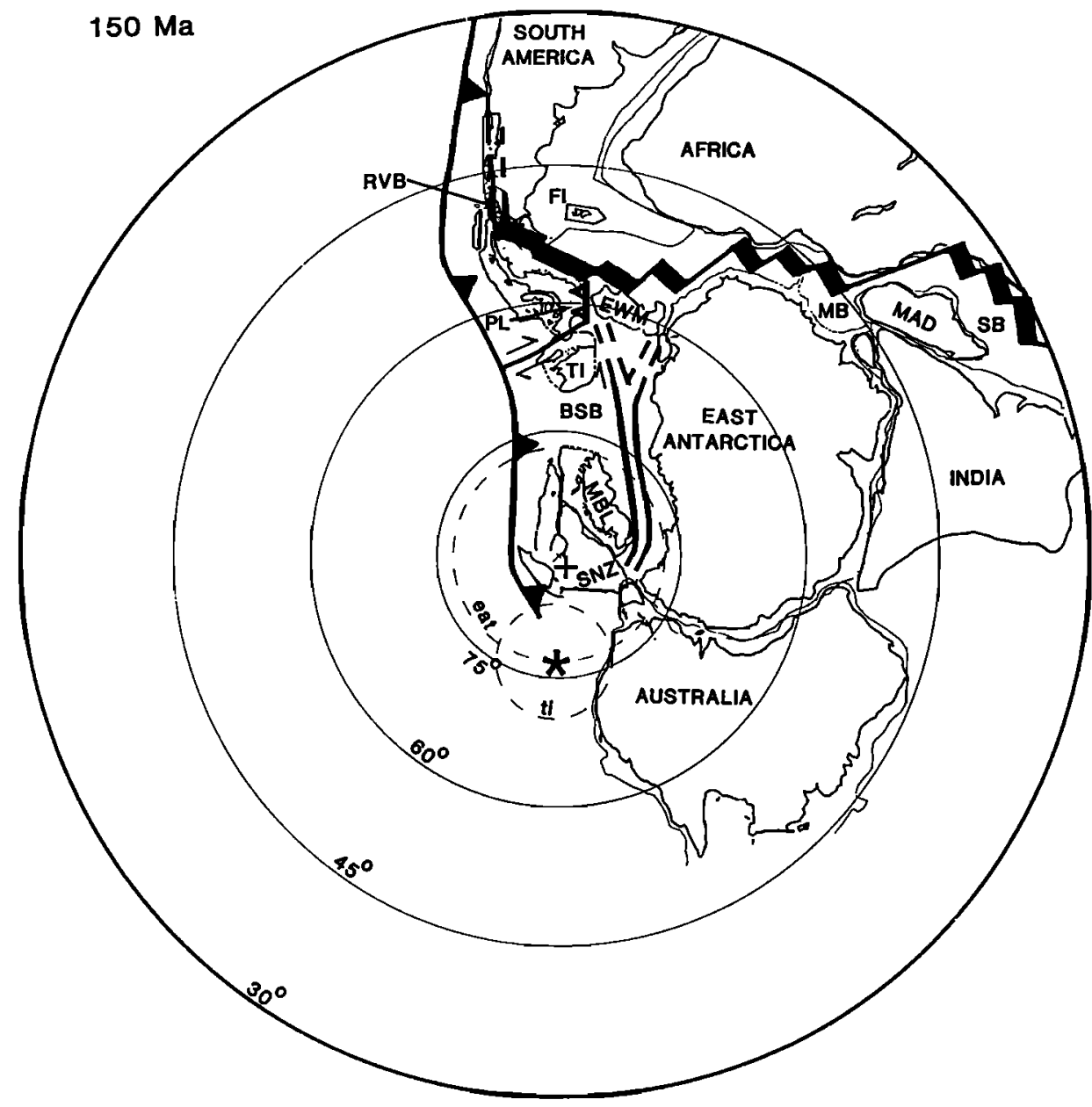

Fig. 5c. Reconstruction for $150 \mathrm{Ma}$; caption same as Figure $5 a$. Between $\geq 150 \mathrm{Ma}$ and $\sim 130 \mathrm{Ma}$, the TI block underwent counterclockwise rotation with respect to East Antarctica. This rotation may have been caused by collision and shearing of the EWM block with the AP and TI blocks in a dextral transpressional zone as the EWM block moved southward during opening of the Mozambique (MZB) and Somali (SB) basins. We relate the Palmer Land (PL) deformational event to the shearing of the EWM block against the AP block and closure of the backarc basin in this region,

5e). The paleomagnetic poles from Lepley Nunatak-Jones Mountains and McNamara Island-Dustin Island are very similar to the $-95 \mathrm{Ma}$ and $\sim 110 \mathrm{Ma}$ poles from the Antarctic Peninsula [Watts et al., 1984; Kellogg and Rowley, 1989] and East Antarctica (Table 4 and Figure 4). The McNamara Island and Dustin Island diorite poles are virtually identical to that obtained from the base of the AP block by Kellogg and Rowley [1989]. Although oroclinal bending at the base of the AP block has been proposed to explain the difference in the $\sim 110 \mathrm{Ma}$ versus 95 Ma AP poles [Kellogg, 1980; Kellogg and Rowley, 1989], we find the agreement of our TI poles with the AP poles to favor rapid apparent polar wander [Watts et al., 1984].

The marine magnetic anomaly data show that by C34 time (84 Ma), East Antarctica and Weddellia were locked together [LaBrecque and Barker, 1981] (Table 6). The paleomagnetic data suggest that this locking of the plates occurred earlier $(\sim 110 \mathrm{Ma})$ within the Cretaceous Normal Polarity interval between M0 and C34 (118-84 Ma). At 110-115 Ma, a major change took place in the South Atlantic and Mozambique basin opening histories [Rabinowitz and LaBrecque, 1979; Besse and Courtillot, 1988]. The rotation pole of South Atlantic opening changed at $\sim 115 \mathrm{Ma}$ [Rabinowitz and LaBrecque, 1979] (using the DNAG time scale) and at $\sim 110 \mathrm{Ma}$ rifting in the Mozambique basin transfered to the eastern Indian Ocean [Besse and Courtillot, 1988]. This reorganization event may have also altered the Weddell Sea opening history such that
Weddellia and East Antarctica became locked together. The geologic histories of southern South America and the Antarctic Peninsula also diverged in the mid-Cretaceous when the Rocas Verdes basin began to close [Dalziel, 1981] while the Weddell Sea basin continued to open (Table 6).

The mid-Cretaceous $(90-110 \mathrm{Ma})$ paleomagnetic pole from MBL, assuming that the rocks have not been regionally tilted [Grindley and Oliver, 1983], does not fall on the common apparent polar wander path for either Weddellia or East Antarctica suggestive of some relative motion between not only MBL and East Antarctica [Grindley and Oliver, 1983] but also MBL and Weddellia (Figure $5 e$ ). We have shown the MBL paleomagnetic pole on the $90 \mathrm{Ma}$ reconstruction although the ages of the MBL rocks range up to $110 \mathrm{Ma}$ and comparison with an older reference pole may be necessary upon refinement of the MBL ages. The MBL data suggest possible displacement of $200-500 \mathrm{~km}$ and dextral rotation of $10^{\circ}-45^{\circ}$ with respect to East Antarctica [Grindley and Oliver, 1983]. MBL may have moved away from East Antarctica during the Late Cretaceous to Tertiary stretching of continental crust in the Ross Sea (Figure 5e) [Cooper et al., 1991; Wilson, 1991], coinciding with rifting between MBL and New Zealand [Mayes et al., 1990]. During this time, dextral transtensional motion would be expected between MBL and East Antarctica, while dextal motion with a compressional component of convergence would be expected between MBL and Weddellia. Antarctica broadly 


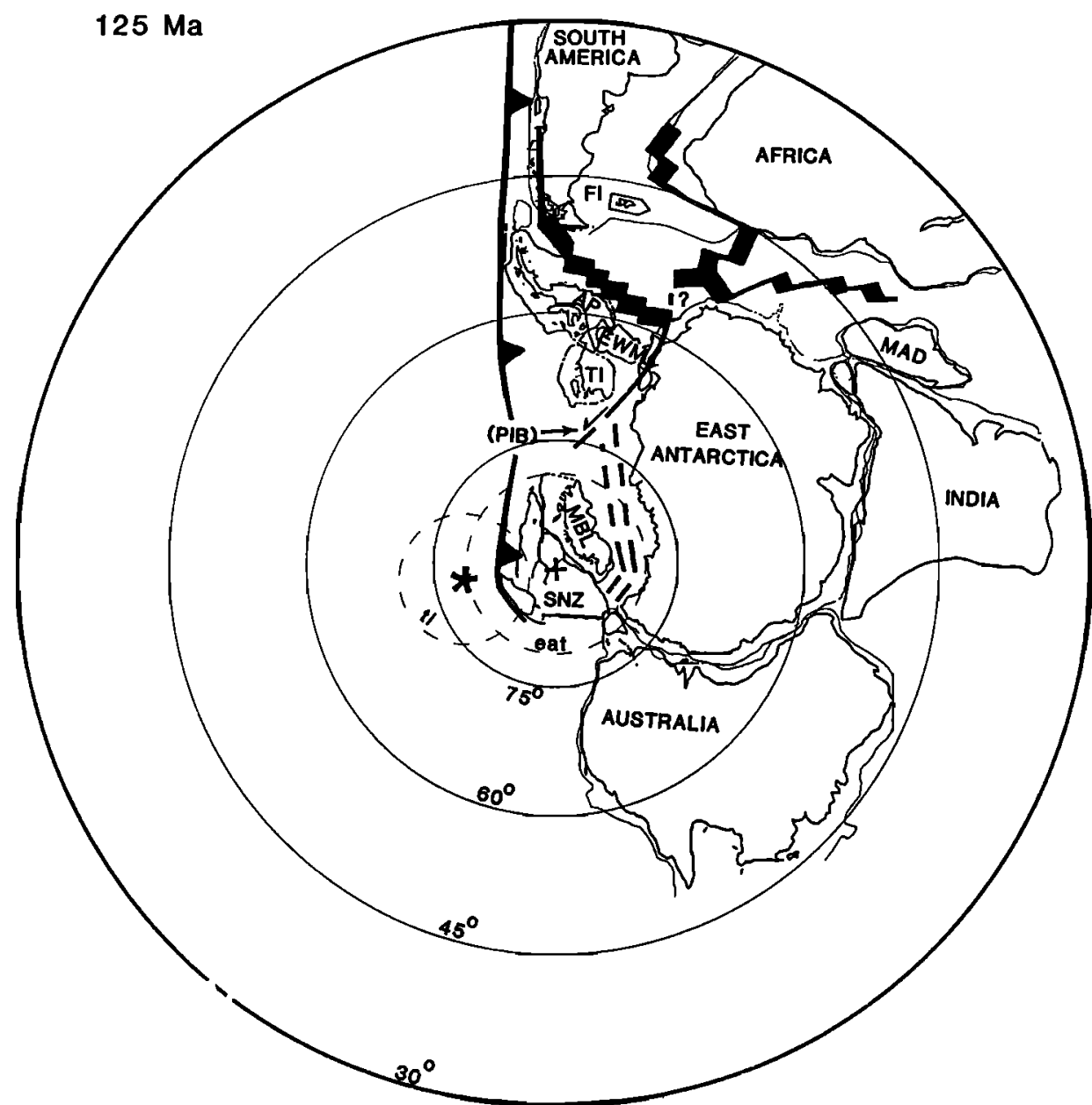

Fig. 5d. Reconstruction for $125 \mathrm{Ma}$; caption same as Figure $5 a$. At $\sim 130 \mathrm{Ma}$, the South Alantic began to open and may have changed the opening history in the Weddell Sea basin such that the EWM block became attached to the AP and TI blocks. A $\sim 30^{\circ}$ clockwise rotation of these three blocks, called Weddellia, translated the EWM block $\sim 750 \mathrm{~km}$ to its present-day position with respect to East Antarctica. A RFF triple junction is shown in the eastem Weddell Sea to provide the mechanism for Weddellia's rotation. We have tentatively connected the RFF triple junction to a RRR triple junction in the northeastem Weddell Sea. Opening of the Rocas Verdes basin may have ceased with initiation of rifting in the South Atlantic and shearing between the northem AP block and southem South America may have occurred.

attained its present configuration by the mid-Tertiary [Lawver et al., 1991] although there are some younger extensional basins found in the western Ross Sea [Cooper et al., 1991] (Figure 5e, inset).

The offset of TI from the MBL coastline in the Pine Island Bay area marks a major geologic boundary in West Antarctica. Rotation of Weddellia and MBL in the Early and Late Cretaceous, respectively, is likely to have caused shearing in the Pine Island Bay region. In addition, Pine Island Bay separates the Cretaceous convergent margin tumed passive margin of the TI block from the solely passive margin evolution of the MBL block. The onshore trace of the Undintsev Fracture Zone (dextral offset) appears to enter the Pine Island Bay area [Sandwell and McAdoo, 1988] and may reflect the oceanic continuation of the major shear zone between Weddellia and MBL. Therefore the Pine Island Bay area marks a very fundamental and long-lived, complex tectonic boundary within West Antarctica.

\section{TECTONIC CONCLUSIONS}

The Mesozoic relative motion of the three West Antarctic crustal blocks of the Antarctic Peninsula, Ellsworth-Whitmore Mountains, and Thurston Island-Eights Coast appears to be linked to three major events during the evolution of the southern ocean basins. Weddellia, consisting of the AP-EWMTI blocks, was in its present-day position with respect to East Antarctica by $100-110 \mathrm{Ma}$. We associate the suturing of Weddellia to East Antarctica with the mid-Cretaceous change in plate motions in the South Atlantic [Rabinowitz and LaBrecque, 1979] and Indian Ocean basins [Besse and Courtillot, 1988]. Paleomagnetic data from Marie Byrd Land [Grindley and Oliver, 1983] appear to indicate relative motion of MBL with respect to both East Antarctica and Weddellia since the mid-Cretaceous. The relative motion of MBL with respect to Weddellia may have occurred along a dextral strikeslip zone(s) associated with extension in the Ross Sea and beneath the Ross Ice Shelf. The Early Cretaceous pole from TI indicates that $\sim 30^{\circ}$ clockwise rotation of Weddellia with respect to East Antarctica occurred between $\sim 125 \mathrm{Ma}$ and $\sim 110$ Ma. We relate this to a major opening phase in the Weddell Sea basin following initiation of South Atlantic basin opening at $\sim 130 \mathrm{Ma}$. If the EWM block were rigidly attached to Weddellia at $125 \mathrm{Ma}$, sinistral shear motion of $\sim 750 \mathrm{~km}$ would be expected between the EWM block and East Antarctica. However, some of this motion may have been taken up between the AP-TI blocks [Grunow et al., 1987b].

Results from the Jurassic rocks indicate that the TI block underwent major counterclockwise rotation with respect to East Antarctica between $\sim 164 \mathrm{Ma}$ and $125 \mathrm{Ma}$. We relate the TI 


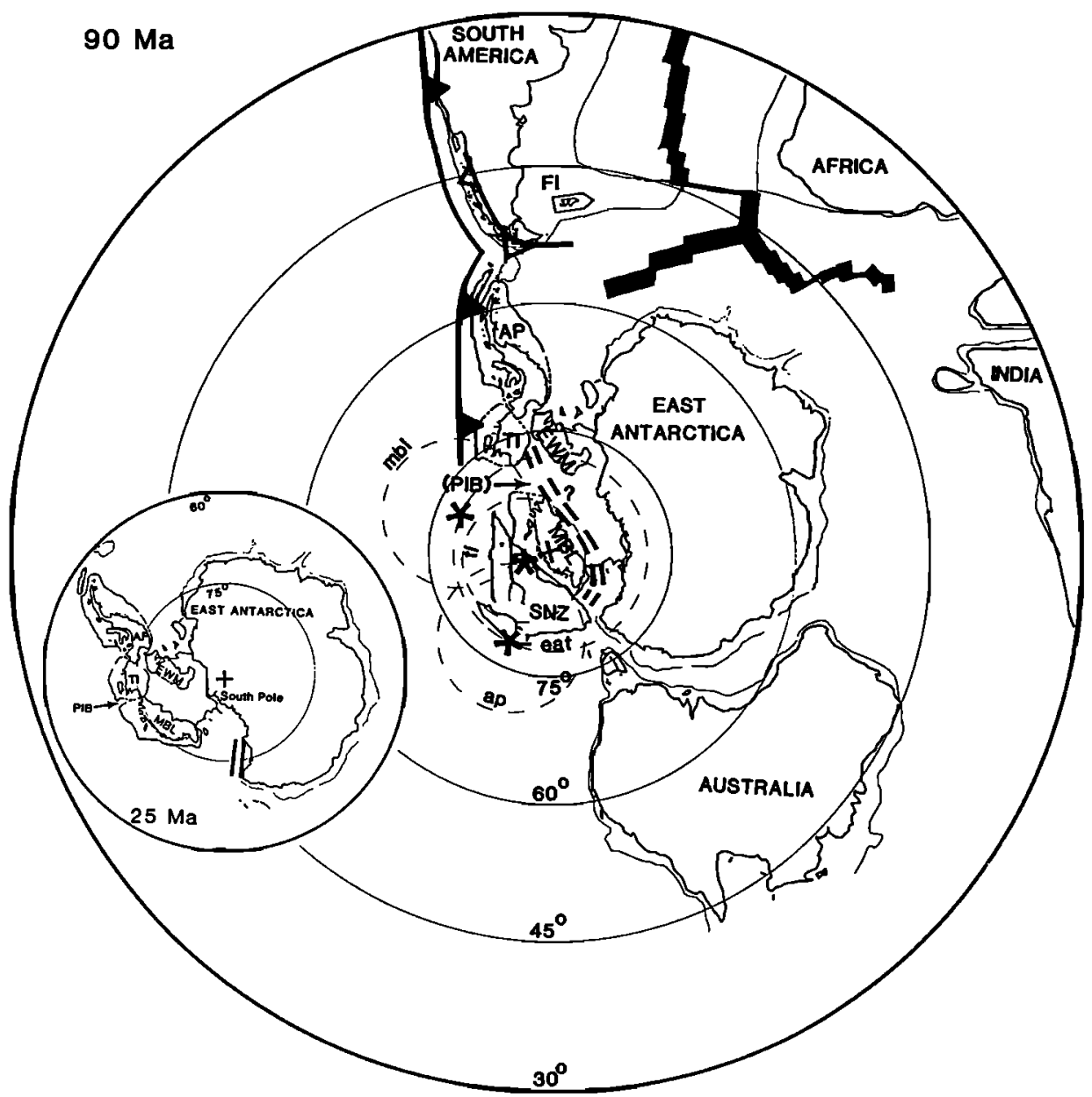

Fig. 5e. Reconstruction for $90 \mathrm{Ma}$; caption same as Figure 5a. The AP and TI poles are indistinguishable from the East Antarctic pole, therefore we leave Weddellia in its present-day position with respect to East Antarctica. Locking of Weddellia with East. Antarctica occurred by around $\sim 110 \mathrm{Ma}$ and may have been a consequence of a change in the South Atlantic rotation pole. Overall dextral motion is predicted between MBL and Weddellia between the mid-Cretaceous and the the present. Although the MBL pole is shown on the $90 \mathrm{Ma}$ reconstruction, the rocks actually range between $90 \mathrm{Ma}$ and $110 \mathrm{Ma}$. It is likely that Pine Island Bay marks a major tectonic boundary in West Antarctica. Inset is $25 \mathrm{Ma}$. East and West Antarctica are broadly in their presentday configuration.

block rotation and the AP block Palmer Land deformational event to dextral shearing and collision of the EWM block against the southeastern AP and TI blocks during this time interval. The tectonic driving mechanism for the TI rotation was provided by Weddell Sea basin rifting connected with opening in the Mozambique and Rocas Verdes basins. Triassic to Early Jurassic rotation of the EWM block and perhaps the FI could be associated with accommodation of the continental crust along major strike-slip shear zones after the Gondwanide Orogeny and preceding the main breakup of Gondwanaland.

Acknowledgments. This work was supported by the Division of Polar Programs, National Science Foundation through grants DPP 82-13798 and DPP 86-43441 to I.W.D.D. and by the British Antarctic Survey (BAS), National Environmental Research Council. We are grateful to the VXE6 Squadron of the U.S. Navy and the BAS air unit for their logistical support. Very special thanks to Chuck Kroger, ourmountaineering expert, and to Chris Marone for their help in collecting the paleomagnetic samples. The radiometric constraints were essential for the interpretation of the data and we are grateful to Robert Pankhurst and Ian Millar at BAS and Mark Harrison and Matt Heizler at UCLA for their help. The tectonic reconstructions were made with the assistance of Lanry Lawver and Lisa Gahagan using an Evans and Sutherland terminal at the Institute for Geophysics, University of Texas at Austin. Discussions with Robin Bell, Terry Wilson, and especially Lamy Lawver as well as comments by reviewer John Geissman and an anonymous reviewer significantly improved this paper. University of Texas Institute for Geophysics contribution 888.

\section{REFERENCES}

Barron,E.J., G.G.A. Harrison, and W.W. Hay, A revised reconstruction of the southem continents, Eos Trans.AGU, 59, 436-450, 1978.

Beck, M.E., Jr., Analysis of Late Jurassic-Recent paleomagnetic data from active plate margins of South America, Jour. S. Am. Earth Sci., 1, 39-52, 1989.

Bell, R.E., High resolution marine and airbome gravity surveys: Applications to rifted margins, Ph.D thesis, Columbia Univ., New York, 1989.

Bell, R.E., J.M. Brozena, W.F. Haxby, and J.L. LaBrecque, Continental margins of the Westem Weddell Sea: Insights from aibome gravity and Geosat-derived gravity, in Contributions to Antarctic Research 1, Antarct. Res. Ser., vol. 50, pp. 91-102, AGU, Washington, D.C.,1990.

Besse, J., and V. Courtillot, Paleogeographic maps of the continents bordering the Indian Ocean since the Early Jurassic, J. Geophys. Res., 93, 11, 791$11,808,1988$.

Bradshaw, J.D., P.B. Andrews, and B.D. Field, Swanson Formation and related rocks of Marie Byrd Land and a comparison with the Robertson Bay Group of northem Victoria Land, in Antarctic Earth Science, edited by R.L. Oliver, P.R. James, and J.B. Jago, pp. 274-279, Australian Academy of Science, Canberra, 1983.

Cooper, A.K., F.J. Davey, and K. Hinz, Crustal extension and origin of sedimentary basins beneath the Ross Sea and Ross Ice Shelf, Antarctica, in Geological Evolution of Antarctica, edited by M.R. A. Thomson, J.A. Crame, and J.W. Thomson, pp. 285-292, Cambridge University Press, New York, 1991.

Craddock, C., T.W. Bastien, and R.H. Rutford, Geology of the Jones Mountains area, in Antarctic Geology, SCAR Proceedings, edited by R.J. Adie,pp. 171-187, North-Holland Publishing Company, Amsterdam, 1964a. Craddock, C., P.W. Gast, G.N. Hanson, and H. Linder, Rubidium-Strontium 
ages from Antarctica, Geol. Soc. Am. Bull., 75, 237-240, $1964 b$.

Craddock, C., C.M. White, and R.H. Rutford, The geology of the Eights Coast, Antarct. J. U.S., 4, 93-94, 1969.

Cunningham, D., K. Klepeis, W. Gose and I.W.D. Dalziel, The Patagonian Orocline: New paleomagnetic data from the Andean magmatic arc in Tierra del Fuego, J. Geophys. Res., in press, 1991.

Dalziel, I.W.D., Back-arc extension in the southern Andes: A review and critical reappraisal, Philos. Trans. R. Soc. London, Ser. A, 300, 319-335, 1981.

Dalziel, I.W.D., and D.H. Elliot, West Antarctica: Problem child of Gondwanaland, Tectonics, 1, 3-19, 1982.

Dalziel, I.W.D., and A.M. Grunow, Late Gondwanide tectonic rotations within Gondwanaland, Tectonics, in press, 1991.

Dalziel, I.W.D., and R.J. Pankhurst, Joint U.K.-U.S. West Antarctic tectonics project: An introduction, in Gondwana Six: Structure,Tectonics and Geophysics, Geophys. Monogr. Ser., vol 40, edited by G.D. McKenzie, pp. 107-108, AGU, Washington, D.C., 1987.

Dalziel, I.W.D., B.C. Storey, S.W. Garrett, A.M. Grunow, L.D.B. Herrod, and R.J. Pankhurst, Extensional tectonics and the fragmentation of Gondwanaland, in Continental Extensional Tectonics, edited by M.P. Coward, J.F. Dewey, and P.L. Hancock, Geol. Soc. Spec. Publ. London, 28, 433-441, 1987.

Delisle, G., Results of Paleomagnetic Investigations in northem Victoria Land, Antarctica, in Antarctic Earth Science, edited by R.L. Oliver, P.R. James, and J.B. Jago, pp.146-155, Australian Academy of Science, Canberra, 1983.

De Wit, M.J., The evolution of the Scotia Arc as a key to the reconstruction of southwestem Gondwanaland, Tectonophysics, 37, 53-81, 1977.

Drake, A.A., Jr., T.W. Stem, and H.H. Thomas, Radiometric ages of zircon and biotite in quartz diorite, Eights Coast, Antarctica, U.S. Geol. Surv. Prof. Pap., 501-D, D50-D53, 1964.

du Toit, A.L, Our Wandering Continents, 366 pp., Oliver and Boyd, Edinburgh, 1937.

Elliot, D.H., Triassic-Early Cretaceous evolution of Antarctica, in Geological Evolution of Antarctica, edited by M.R.A. Thomson, J.A. Crame, and J.W. Thomson, pp. 541-548, Cambridge University Press, New York, 1991.

Fisher, R.A., Dispersion on a sphere, Proc. R. Soc. London, Ser. A, 217, 295-305, 1953.

Garrett, S.W., L.D.B. Herrod, and D.R.Mantripp, Crustal structure of the area around Haag Nunataks, West Antarclica: New aeromagnetic and bedrock elevation data, in Gondwana Six: Structure, Tectonics and Geophysics, Geophys. Monogr. Ser., vol. 40, edited by G.D. McKenzie, pp. 109-115, AGU, Washington, D.C., 1987.

Grindley, G.W.. and P.J. Oliver, Paleomagnetism of Cretaceous volcanic rocks from Marie Byrd Land, in Antarctic Earth Science, edited by R.L. Oliver, P.R. James, and J.B. Jago, Pp. 573 -578, Australian Academy of Science, Canberra, 1983.

Grunow, A.M., I.W.D. Dalziel, and D.V. Kent, Ellsworth-Whitmore Mountains crustal block, westem Antarctica: New paleomagnetic results and their tectonic significance, in Gondwana Six: Structure, Tectonics and Geophysics, Geophys.Monogr. Ser., vol. 40, edited by G.D. McKenzie, pp. 161-171, AGU, Washington, D.C., $1987 a$.

Grunow, A.M., D.V. Kent, and I.W.D. Dalziel, Mesozoic evolution of West Antarctica and the Weddell Sea Basin: New paleomagnetic constraints, Earth Planet. Sci. Lett., 86, 16-26, $1987 b$.

Grunow, A.M., D.V. Kent, and I.W.D. Dalziel, New Paleomagnetic data bearing on the Mesozoic evolution of West Antarctica and opening of the Weddell Sea, Geol. Soc. Am. Abstr. Programs, 22, 143-144, 1990.

Harrison, S.M., and W.P. Loske, Early Paleozoic U-Pb isotopic age for an orthogneiss from north-western Palmer Land, Antarctic Peninsula, Br. Antarct. Surv. Bull., 81, 11-18, 1988.

Irving, E., and G.A. Irving, Apparent polar wander paths Carboniferous through Cenozoic and the assembly of Gondwana, Geophys. Surv., S, 141 $188,1982$.

Jankowski, E.J., and D.J. Drewry, The structure of West Antarctica from geophysical studies, Nature, 291, 17-21, 1981.

Kellogg, K., Paleomagnetic evidence for oroclinal bending of the southern Antarctic Peninsula, Geol. Soc. Am. Bull., 91, 414-420, 1980.

Kellogg, K., and P.D. Rowley, Structural geology and tectonics of the Orville Coast region, southem Antarctic Peninsula, Antarctica, U.S. Geol. Surv. Prof. Pap., 1498, 25 pp., 1989.

Kirschvink, J.L., The least-square line and plane analysis of paleomagnetic data, Geophys.J. R. Astron. Soc., 62, 699-718, 1980.

Kristoffersen, Y., and K. Haugland, Geophysical evidence for the East Antarctic plate boundary in the Weddell Sea, Nalure, 322, 538-541, 1986. LaBrecque, J.L., Southem Atlantic Ocean and adjacent Antarctic Continental Margin, in Ocean Margin Drilling Project, Reg. Data Synthesis Ser., Allas
13, Marine Science Intemational, Woods Hole, Mass., 1985.

LaBrecque, J.L., and P. Barker, The age of the Weddell Basin, Nature, 290, 489-492, 1981.

Lawver, L.A., and C.R. Scotese, A revised reconstruction of Gondwanaland, in Gondwana Six: Structure, Tectonics and Geophysics, Geophys. Monogr. Ser., vol. 40, edited by G.D. McKenzie, pp. 17-23, AGU, Washington,

D.C., 1987.
Lawver, L.A., J.Y. Royer, D.T. Sandwell, and C.R. Scotese, Evolution of the Antarctic continental margins, in Geological Evolution of Antarctica, edited by M.R.A. Thomson, J.A. Crame, and J.W. Thomson, Pp. 533-540, Cambridge University Press, New York, 1991.

Longshaw, S.K., and D.H. Griffiths, A paleomagnetic study of Jurassic rocks from the Antarctic Peninsula and its implications, J. Geol. Soc. London, $140,945-954,1983$.

Lopatin, B.G., and E.M. Orlenko, Outline of the geology of Marie Byrd Land and the Eights Coast, in Antarctic Geology and Geophysics, edited by R.J. Adie, pp. 843-847, Universitetesforlaget, Oslo, 1972.

Lorenzo, J.M., and J.C. Mutter, Seismic stratigraphy and tectonic evolution of the Falkland/Malvinas plateau, Revista Brasileira de Geociencias, 18, 191-200, 1988.

Løvlie, R., Mesozoic paleomagnetism in Vestfjella, Dronning Maud Land, East Antarctica, Geophys. J. R. Astron. Soc., 59, 529-537, 1979.

Martin, A.K., and C.J.H. Hartnady, Plate tectonic development of the south west Indian Ocean: A revised reconstruction of East Antarctica and Africa, J. Geophys. Res., 91, 4767-4786, 1986.

Mayes, C.L., L.A. Lawver, and D.T. Sandwell, Tectonic history and new isochron chart of the South Pacific, J.Geophys. Res., 95, 8543-8567, 1990.

Meneilly, A.W., S.M. Harrison, B.A. Piercy, and B.C. Storey, Structural evolution of the magmatic arc in northem Palmer Land Antarctic Peninsula, in Gondwana Six: Structure, Tectonics and Geophysics, Geophys. Monogr. Ser, vol. 40, edited by G.D. McKenzie, pp. 209-219, AGU, Washington, D.C., 1987.

Millar I., and R.J. Pankhurst, Rb/Sr geochronology in the region between the Antarctic Peninsula and the Transantarctic Mountains: Haag Nunataks and Mesozoic granitoids, in Gondwana Six: Structure,Tectonics andGeophysics, Geophys. Monogr.Ser, vol. 40, edited by G.D. McKenzie, pp. 151-160, AGU, Washington, D.C., 1987.

Milne, A.M., and L.L. Millar, Mid-Paleozoic basement in eastern Graham Land and its relation to east Antarctica, Geological Evolution of Antarctica, edited by M.R.A. Thomson, J.A. Crame, and J.W. Thomson, Pp. 335-340, Cambridge University Press, New York, 1991.

Mukasa, S.B., I.W.D. Dalziel, and H.K. Brueckner, Zircon U-Pb constraints on the kinematic evolution of the northem Scotia Arc, Geol. Soc. Am. Abstr. Programs, 20, A12, 1988.

Norton, I.O., and J.G. Sclater, A model for the evolution of the Indian Ocean and the breakup of Gondwanaland, J. Geophys. Res., 84, 6803-6830, 1979.

Palmer, A.R., The decade of North American Geology geologic time scale, Geology, 11, 503-504, 1983.

Pankhurst, R.J., Rb-Sr geochronology of Graham Land, Antarctica, J. Geol. Soc. London, 139, 701-712, 1982.

Pankhurst, R.J., Rb-Sr constraints on the ages of basement rocks of the Antarctic Peninsula, in Antarctic Earth Science, edited by R.L. Oliver, P.R. James, and J.B. Jago, pp. 367-372, Australian Academy of Science, Canberra, 1983.

Pankhurst, R.J., The Paleozoic and Andean magmatic arcs of West Antarctica and southem South America, Spec. Pap. Geol. Soc. Am., 241, 1-7, 1990.

Powell, C.M., B.D. Johnson, and JJ.Y. Veevers, A revised fit of East and West Gondwanaland, Tectonophysics, 63, 13-30, 1982.

Rabinowitz, P.D., and J. LaBrecque, The Mesozoic South Atlantic Ocean and evolution of its continentalmargins, J. Geophys. Res., 84,5973-6002, 1979.

Rabinowitz, P.D., M.F. Coffin, and D. Dalvey, The separation of Madagascar and Africa, Science, 220, 67-69, 1983.

Rapela, C.W., R.J. Pankhurst, and S.M. Harrison, Gondwana plutonism of northem Patagonia, in International Geological Congress Abstracts, 2 ,675 pp., AGU, Washington, D.C., 1989.

Rutford, R.H., C. Craddock, C.M. White, and R.L. Armstrong, Tertiary glaciation in the Jones Mountains, in Anlarctic Geology and Geophysics, edited by R.J. Adie, pp. 239-243, Universitetesforlaget, Oslo, 1972.

Sandwell, D.T., and D.C. McAdoo, Marine gravity of the southem ocean and Antarctic margin from Geosat, J. Geophys.Res., 93, 10, 389-10,396, 1988. Schamberger, C.H., and L. Sharon, Paleomagnetism and plate tectonics of Antarctica, in Antarctic Geology and Geophysics, edited by R.J. Adie, pp. 843-847, Universitetesforlaget, Oslo, 1972.

Schlopf, J.M., Ellsworth Mountains: Position in West Antarctica due to seafloor spreading, Science, 164, 63-66, 1969.

Segoufin, J., and P. Patriat, Existence d'anomalies mesozoiques dans le bassin de Somalie, implications pour les relations Afrique-AntartiqueMadagascar, C.R. Acad. Sci., Ser. B 291, 85-88, 1980. 
Simpson, E.S.W., J.G. Sclater, B. Parsons, I. Norton, and L. Meinke, Mesozoic magnetic lineations in the Mozambique Basin, Earth Planet. Sci. Lett., 43, 260-264, 1979.

Smellie, J.L., A complete arc-trench system recognized in Gondwana sequences of the Antarctic Peninsula region, Geol.Mag. 118, 139-159, 1981. Smith, A.G., and A. Hallam, The fit of southem continents, Nature, 225, 139$149,1970$.

Storey, B.C., and I.W.D. Dalziel, Outline of the structural and tectonic history of the Ellsworth Mountains-Thiel Mountains Ridge, West Antarctica, in Gondwana Six: Structure, Tectonics and Geophysics, Geophys. Monogr. Ser., vol. 40, edited by G.D. McKenzie, pP. 117-128, AGU, Washington, D.C., 1987.

Storey, B.C., R.J.Pankhurst, I. Miller, I.W.D. Dalziel, and A.M. Grunow, The geology of Thurston Island, Antarctica, Geological Evolution of Antarcsica, edited by M.R.A. Thomson, J.A. Crame, and J.W. Thomson, Pp. 339 404, Cambridge University Press, Cambridge, 1991.

Suarez, M., Plate tectonic model for southem Antarctic Peninsula and its relation the southem Andes, Geology, 4, 211-214, 1976.

Taylor, G.K., and J. Shaw, The Falkland Islands: New palaeomagnetic data and their origin as a displace terrane from southem Africa, in Deep Structure and Past Kinematics of Accreted Terranes, Geophys. Monogr. Ser., vol. 50, edited by J.W. Hillhouse, pp. 59-72, AGU, Washington, D.C., 1989.

Thomson, M.R.A., Mesozoic paleogeography of West Antarctica, in Antarctic Geoscience, edited by C. Craddock, pp. 331-337, University of Wisconsin Press, Madison, 1982.

Thomson, M.R.A., and R.J. Pankhurst, Age of post-Gondwanian calcalkaline volcanism in the Antarctic Peninsula Region, in Antarctic Earth Science, edited by R.L. Oliver, P.R. James, and J.B. Jago, Pp. 328-333, Australian Academy of Science, Canberra, 1983.

Wade, F.A., and J.R. Wilbanks, Geology of Marie Byrd and Ellsworth Lands, in Antarctic Geology and Geophysics, edited by R.J. Adie, Pp. 207-214, Universitetesforlaget, Oslo, 1972.
Watts, A.B., J.K. Weissel, R.A. Duncan, and R.L. Larson, Origin of the Louisville Ridge and its relationship to the Eltanin Fracture Zone System, J. Geophys. Res., 93, 3051-3077, 1988.

Watts, D.R., Potassium-argon ages and paleomagnetic results from King George Island, South Shetland Islands, in Antarctic Geoscience, edited by C. Craddock, pp. 255-261, University of Wisconsin Press, Madison, 1982. Watts, D.R., and A.M. Bramall, Paleomagnetic evidence for a displaced terrain in westem Antarctica, Nature, 293, 638-641, 1981.

Watts, D.R., G.C. Watus, and A.M. Bramall, Cretaceous and Early Tertiary paleomagnetic results from the Antarctic Peninsula, Tectonics, 3, 333-346, 1984.

Webers, G.F., and K.B. Sporli, Palaeontological and stratigraphic investigations in the Ellsworth Mountains, West Antarctica, in Antarctic Earth Science, edited by R.L. Oliver, P.R. James, and J.B. Jago, Pp. 261-264, Australian Academy of Science, Canberra, 1983.

Whitham, A.G., and B.C. Storey, Late Jurassic-Early Cretaceous strike-slip deformation in the Nordenskjöld Formation of Graham Land, Antarct. Sci. 1, 269-278, 1989.

Wilson, T.J., Mesozoic and Cenozoic structural patterns in the Transantarctic Mountains, Antarct. J. US., in press, 1991.

I.W.D. Dalziel, Institute for Geophysics, University of Texas at Austin, 8701 Mopac Blvd., Austin, TX 78759.

A.M. Grunow, Department of Earth Sciences, University of Oxford, Parks Road, Oxford, OX1 3PR, England.

D.V. Kent, Lamont-Doherty Geological Observatory, Palisades, NY 10964.

Received November 7, 1990; revised May 1, 1991; accepted June 5, 1991.) 